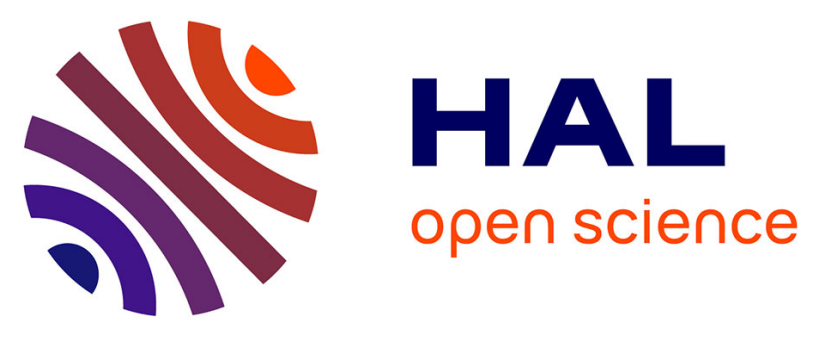

\title{
Zirconium-hafnium and rare earth element signatures discriminating the effect of atmospheric fallout from hydrothermal input in volcanic lake water
}

Claudio Inguaggiato, P. Censi, Pierpaolo Zuddas, W. d'Alessandro, L. Brusca, G. Pecoraino, S. Bellomo

\section{To cite this version:}

Claudio Inguaggiato, P. Censi, Pierpaolo Zuddas, W. d'Alessandro, L. Brusca, et al.. Zirconiumhafnium and rare earth element signatures discriminating the effect of atmospheric fallout from hydrothermal input in volcanic lake water. Chemical Geology, 2016, 433, pp.1-11. 10.1016/j.chemgeo.2016.04.002 . hal-01313018

\section{HAL Id: hal-01313018 \\ https: / hal.sorbonne-universite.fr/hal-01313018}

Submitted on 9 May 2016

HAL is a multi-disciplinary open access archive for the deposit and dissemination of scientific research documents, whether they are published or not. The documents may come from teaching and research institutions in France or abroad, or from public or private research centers.
L'archive ouverte pluridisciplinaire HAL, est destinée au dépôt et à la diffusion de documents scientifiques de niveau recherche, publiés ou non, émanant des établissements d'enseignement et de recherche français ou étrangers, des laboratoires publics ou privés. 


\title{
Zirconium-hafnium and rare earth element signatures discriminating the effect of atmospheric fallout from hydrothermal input in volcanic lake water
}

\author{
Inguaggiato C. ${ }^{1,2,3^{*}}$, Censi P. ${ }^{1,}$, Zuddas P. ${ }^{2}$, D'Alessandro W. ${ }^{3}$, Brusca L. ${ }^{3}$, \\ Pecoraino G. ${ }^{3}$, Bellomo S. ${ }^{3}$
}

1. Dipartimento di Scienze della Terra e del Mare, Università degli Studi di Palermo, Via Archirafi, 22 - 90123 Palermo, Italy.

2. UPMC-Sorbonne Universités, Institut des Sciences de la Terre de Paris, 4 place Jussieu, F75005 Paris, France

3. Istituto Nazionale di Geofisica e Vulcanologia, Sezione di Palermo, Via U. La Malfa, 153, 90146 Palermo, Italy.

*corresponding author: claudio.inguaggiato@unipa.it; +39 3381479801

Keywords: Rare Earth Elements; Zirconium; Hafnium; $\mathrm{CO}_{2}$-rich waters; Lake; Aeolian input;

\begin{abstract}
Geochemical behaviour of rare earth elements (REE), $\mathrm{Zr}$, and $\mathrm{Hf}$ was investigated in $\mathrm{CO}_{2}$-rich waters circulating in Pantelleria Island also including 'Specchio di Venere' Lake within a calderic depression. A wide range of total dissolved REE concentrations was found (2.77-12.07 $\left.\mathrm{nmol} \mathrm{L}{ }^{-1}\right)$, with the highest contents in the lake. The main REE complexes in the $\mathrm{CO}_{2}$-rich waters are $\left[\operatorname{REE}\left(\mathrm{CO}_{3}\right)_{2}\right]^{-}$and $\left[\mathrm{REECO}_{3}\right]^{+}$, showing changeable proportions as a function of $\mathrm{pH}$. The REE normalized to post-Archean Australian Shale (PAAS) showed similar features with heavy REE (HREE) enrichments in $\mathrm{CO}_{2}$-rich waters collected from springs and wells, whereas a different $\mathrm{REE}$ pattern was found in the 'Specchio di Venere' Lake water with middle REE (MREE) enrichments.
\end{abstract}


The PAAS normalized concentration ratios $(\mathrm{LREE} / \mathrm{HREE})_{\mathrm{N}}$ and $(\mathrm{MREE} / \mathrm{HREE})_{\mathrm{N}}$ in waters are $<1$, except for the lake water in which $(\mathrm{MREE} / \mathrm{HREE})_{\mathrm{N}}>1$. Positive Eu anomalies were found in the investigated waters owing to water-rock interactions with less evolved host rocks. Ce anomalies as a function of Eh values were recognized, with the highest Ce anomaly occurring in the lake water with respect to the $\mathrm{CO}_{2}$-rich waters. The $\mathrm{Y} / \mathrm{Ho}$ and $\mathrm{Zr} / \mathrm{Hf}$ molar ratios are higher in the investigated waters (except for lake water) than that in the local rocks, with values ranging from 35.4 to 77.9 and from 76.3 to 299 , respectively. The precipitation of authigenic phases was considered to be responsible for the increase in the $\mathrm{Y} / \mathrm{Ho}$ and $\mathrm{Zr} / \mathrm{Hf}$ ratios owing to enhanced $\mathrm{Hf}$ and Ho removal with respect to $\mathrm{Zr}$ and $\mathrm{Y}$.

The REE patterns in the lake water show a similar shape (MREE-enriched and a positive Ce anomaly) as those found in the settling dust and in the desert varnish coating of the rocks in arid environments, which mainly contain Fe- and Mn-oxyhydroxides and clay minerals. Similarly, Y/Ho and $\mathrm{Zr} / \mathrm{Hf}$ ratios in the 'Specchio di Venere' Lake (35.4 and 76.3, respectively) show a desert varnish signature. These data, coupled with the presence of iron oxyhydroxides and phyllosilicates in the shallowest water layer of the 'Specchio di Venere' Lake, verify the aeolian input from the Sahara Desert.

\section{Introduction}

In the last few decades, interest in the geochemical behaviour of the rare earth elements (lanthanides and yttrium, defined hereafter as REE), Zr, and Hf, during the fractionation processes between different phases has been growing (Greaves et al., 1994; Bau, 1996, 1999; Censi et al., 2004, 2015; Inguaggiato et al., 2015). The REE are used as tracers for various geochemical processes occurring in natural water systems (Wood, 2003; Piper et al., 2013; Varekamp, 2015 and references therein). 
The REE are arbitrarily divided into three groups: light rare earth elements (LREE) from La to Nd, middle rare earth elements (MREE) from Sm to Dy, and heavy rare earth elements (HREE) from Ho to $\mathrm{Lu}$.

The distribution of $\mathrm{Zr}$, Hf, and the REE dissolved phase is the result of physicochemical conditions, water-rock interactions (precipitation/dissolution of solid phases), and different complexation states as a function of the major anion composition of the water (Millero, 1992; Bau, 1996; Byrne, 2002; Ruberti et al., 2002; Wood, 2003 and references therein). The dissolved Zr, Hf, and REE contents in ocean water are a consequence of continental sources (riverine or atmospheric), hydrothermal input, and the availability of ligands for complexation. The hydrothermal mid-oceanic ridge vent fluids are characterized by higher REE content compared to seawater. However, the precipitation process of Fe- and Mn-oxyhydroxides at the oxidized seawater-reduced hydrothermal fluids interface removes REE from the dissolved phase (Olivarez and Owen 1989; Bau and Dulski, 1999). Considering the last process, the hydrothermal vent fluids appear to be quantitatively negligible as a source of REE in seawater (Wood 2003 and references therein). Atmospherically transported dust leads to a characteristic geochemical signature in dissolved REE (Greaves et al., 1991, 1999). Previous works suggest that atmospheric fallout is an important source of REE in seawater, (Greaves et al., 1994, 1999). The Mediterranean Sea is an epicontinental basin, and the effects of the dissolution of atmospheric fallout are easily shown in the dissolved REE distribution (Greaves et al., 1991; Censi et al., 2004, 2007), whereas the behaviour of $\mathrm{Zr}$ and $\mathrm{Hf}$ is not known.

Only a few studies have focused on Zr and Hf in natural waters (Godfrey et al., 2008, 2009; Censi et al., 2015; Inguaggiato et al., 2015). During the last decade, the scientific community focused its attention on the geochemical processes involving $\mathrm{Zr}$ and $\mathrm{Hf}$ in the aqueous system, often coupling these elements with $\mathrm{Y}$ and $\mathrm{Ho}$ and more recently with $\mathrm{Nb}$ and $\mathrm{Ta}$, recognizing their use as geochemical tracers for water masses in the ocean (Firdaus et al., 2011; Frank, 2011). If the geochemical system is CHarge and RAdius Controlled (CHARAC), involved trace elements with similar charge-to-radius ratios (such as $\mathrm{Y}-\mathrm{Ho}$ and $\mathrm{Zr}$-Hf twin pairs) show the same behaviour, 
whereas their decoupling occurs in the aqueous phase when their electronic configuration plays the main role (Bau, 1996). The $\mathrm{Zr} / \mathrm{Hf}$ in seawater is higher with respect to chondrites, terrestrial rocks, and freshwater, suggesting fractionation within this element pair (Godfrey et al., 2008).

Pantelleria Island is an active volcano, well known for its thermal activity, situated in the centre of the Strait of Sicily. The thermal waters are the result of gas-water-rock interaction with a significant marine water influence (Dongarrà et al., 1983; Parello et al., 2000; Favara et al., 2001). Pantelleria also includes 'Specchio di Venere' Lake, an alkaline water lake within a calderic depression which is fed by a mix of hydrothermal fluids and meteoric inputs (Dongarrà et al. 1983; Aiuppa et al., 2007). The REE behaviour in alkaline lakes is poorly known (Johannesson and Lyons, 1994; Wang et al., 2013), whereas acid volcanic lakes have been characterized for REE by many investigators (Ayres, 2012; Colvin et al., 2013; Varekamp, 2015 and references therein). The geochemistry of dissolved $\mathrm{Zr}$ and $\mathrm{Hf}$ is still poorly known in both types of volcanic lakes (Inguaggiato et al., 2015). Pantelleria represents an ideal site to investigate the geochemical behaviour of the REE, Zr, and Hf in waters resulting from the interactions between rocks, seawater, $\mathrm{CO}_{2}$-rich fluids, and atmospheric particles delivered from the fallout of desert dust under alkaline conditions. In this work, we argue for a strong contribution of the REE, $\mathrm{Zr}$, and $\mathrm{Hf}$ from the atmospheric particle contribution from the Sahara Desert to the 'Specchio di Venere' Lake.

\section{Materials and Methods}

Cold and $\mathrm{CO}_{2}$-rich thermal waters (from springs, wells, and the lake) were collected on Pantelleria Island between May 2014 and July 2014 (Fig. 1). The lake water was sampled in the deepest area, collecting the shallowest water layers $(-30 \mathrm{~cm})$ and the deepest water layers $(-13 \mathrm{~m})$ by using an electric pump operated on an inflatable boat. Samples were collected after filling the entire tube system. Physicochemical parameters (temperature, $\mathrm{pH}$, Eh, and electrical conductivity) were measured in the field. Water samples were immediately filtered through $0.45 \mu \mathrm{m}$ MILLIPORE cellulose acetate filters into $100 \mathrm{~mL}$ Nalgene bottles and then acidified with $\mathrm{HNO}_{3}$ ultrapure in 
order to analyse for the major cations and trace elements (excluding REE, $\mathrm{Zr}$, and Hf). The water samples for the analyses of the major anions were not acidified. Alkalinity was determined in situ by titration with $\mathrm{HCl} 0.1 \mathrm{M}$. A Dionex ionic chromatograph equipped with a CS-12A column was used to determine the major cations ( $\mathrm{Na}, \mathrm{K}, \mathrm{Mg}$, and $\mathrm{Ca}$ ), and another chromatograph equipped with an AS14A column was used to analyse for the major anions $\left(\mathrm{F}, \mathrm{Cl}\right.$, and $\left.\mathrm{SO}_{4}\right)$. An additional litre of sample was collected at each sampling point. It was filtered through $0.45 \mu \mathrm{m}$ Millipore cellulose acetate filters into $1000 \mathrm{~mL}$ Nalgene bottles and then acidified with $\mathrm{HNO}_{3}$ ultrapure. In order to separate and pre-concentrate REE, $\mathrm{Zr}$, and $\mathrm{Hf}$ from this solution, the sample water was treated in the laboratory. Ultrapure ammonia solution was added to each water sample $(1 \mathrm{~L})$ to reach $\mathrm{pH}$ 8. Later, $1 \mathrm{~mL}$ of Fe standard solution $\left(1 \mathrm{~g} \mathrm{~L}^{-1}\right)$ was added to induce the precipitation of solid $\mathrm{Fe}(\mathrm{OH})_{3}$, scavenging quantitatively all REE, Zr, and Hf. Afterwards, the solid phase was separated from the remaining solution by collecting the $\mathrm{Fe}(\mathrm{OH})_{3}$ with a membrane filter $(47 \mathrm{~mm}$ and pore size $0.45 \mu \mathrm{m})$. The $\mathrm{Fe}(\mathrm{OH})_{3}$ was dissolved in ultrapure $\mathrm{HCl} 6 \mathrm{M}$ solution and then diluted (1:6) before analysing the REE, Zr, and Hf with a Q-ICP-MS (Agilent 7500cc). A detailed description of the methodology used to separate and pre-concentrate $\mathrm{REE}, \mathrm{Zr}$, and $\mathrm{Hf}$ is reported in Raso et al. (2013). The trace elements, including REE, Zr, and Hf, were analysed by Q-ICP-MS equipped with a Micromist nebulizer, a Scott double pass spray chamber, a three-channel peristaltic pump, an auto sampler (ASX-500, Cetac), and an octopole reaction system (ORS) to remove the interferences of polyatomic masses and isobaric isotopes. The mass spectrometer was calibrated with a multi-element standard solution with 11 calibration points. The sensitivity variations were monitored using ${ }^{103} \mathrm{Rh},{ }^{115} \mathrm{In}$, and ${ }^{185} \mathrm{Re}$ at a final concentration of $8 \mu \mathrm{g} / \mathrm{L}$ for each, as internal standards were added directly online by an appropriate device that mixes the internal standard solution into the sample just before the nebulizer. A 60 -s rinse using a $0.5 \% \mathrm{HCl}$ and $2 \%$ of $\mathrm{HNO}_{3}$ solution plus a 60 -s rinse using $2 \%$ of $\mathrm{HNO}_{3}$ solution reduced any memory interferences between samples. The precision of the analysis was checked by running five replicates of every standard, and the sample was always within $\pm 10 \%$. Data accuracy was evaluated by analysing standard 
reference materials (Spectrapure Standards SW1 and 2, SLRS4, NIST 1643e, Environment Canada TM 24.3, and TM 61.2) for each analytical session, and the error for each element was $<15 \%$.

Dissolved gases were sampled and analysed following Capasso and Inguaggiato (1998), based on the equilibrium partitioning of gases between a gas host (Ar) and a liquid phase. The analyses for dissolved gases $\left(\mathrm{CO}_{2}, \mathrm{~N}_{2}\right.$, and $\left.\mathrm{O}_{2}\right)$ were performed by using a gas-chromatograph (Clarus 500, Perkin Elmer).

Simulations with PHREEQC software using the LLNL database (version 3.0.6) (Parkhurst and Appelo, 2010) were carried out to calculate the saturation indexes and the REE aqueous speciation at the physicochemical conditions measured in the field.

Scanning electronic microscopy (SEM) observations and energy dispersive X-ray spectra (EDS) analyses were carried out on the suspended particulate matter (SPM) collected during the filtration from the lake water and from the Polla 3 thermal spring along the lake shoreline, in order to get information about the nature of the suspended solids. The filters with the SPM were assembled on the aluminium stub and coated with gold. The analyses were performed with a LEO 440 SEM equipped with an EDS system OXFORD ISIS Link and Si (Li).

The $\mathrm{Eu}$ and $\mathrm{Ce}$ anomalies were calculated with respect to the neighbouring elements normalized to the PAAS (Taylor and McLennan, 1985), using the equation suggested by Alibo and Nozaki (1999):

$\mathrm{REE}_{\mathrm{n}} / \mathrm{REE}_{\mathrm{n}} *=2 \times(\mathrm{REE})_{\mathrm{n}} /\left[(\mathrm{REE})_{\mathrm{n}-1}+(\mathrm{REE})_{\mathrm{n}+1}\right]$

where $(\mathrm{REE})_{\mathrm{n}}$ is the concentration of the element chosen to calculate the anomaly, and (REE) $)_{\mathrm{n}-1}$ and $(\mathrm{REE})_{\mathrm{n}+1}$ represent the previous and the subsequent elements of the REE series, respectively.

\section{Brief description of study area}


Pantelleria Island $\left(83 \mathrm{~km}^{2}\right)$ is an active volcano rising $836 \mathrm{~m}$ above sea level, located in the Strait of Sicily between Sicily and Africa. The rocks in Pantelleria consist largely of trachyte and pantellerite (peralkaline rhyolites), while in the north-western part of the island, alkali basalt and hawaiite occur, representing only $6 \%$ of the total outcrops. The local rocks are characterized by a compositional gap of about $13 \% \mathrm{SiO}_{2}$ between the basaltic rocks and the trachyte. Basaltic lavas are characterized by $20-30$ vol.\% crystals, trachyte lavas have $30-40$ vol.\% crystals, and pantellerite consists of 5-25 vol.\% crystals. Forty rock samples were studied by White et al. (2009), showing REE-enriched normalized REE patterns. The REE concentrations increase with the evolution of the rocks, showing a positive Eu anomaly in the basaltic rocks, a negative to positive Eu anomaly in the trachyte lavas, and a negative anomaly of Eu in the pantellerite lavas and tuffs. The ratios Y/Ho and $\mathrm{Zr} / \mathrm{Hf}$ display relatively constant molar ratios around 49 and 80, respectively, exhibiting chondritic values.

The most recent eruptive activities occurred at the end of the 19th century (in the years 1831, 1845, 1846,1863 , and 1891) about 3-4 $\mathrm{km}$ offshore to the northwest of the island. The volcano-tectonic features of the island include caldera collapses and resurgence inside the youngest caldera. The oldest caldera ('La vecchia caldera') is dated at $114 \mathrm{ka}$, while the youngest ('Monastero caldera') is related to the eruption of the Green Tuff (50 ka). Inside the 'Monastero caldera', resurgence has taken place with the uplifting and tilting of the 'Montagna Grande' block through a simple shearing mechanism. Intra-calderic activity in the last 45 ka (Mahood and Hildreth, 1986; Civetta et al., 1988) indicates the presence of an active magma chamber at crustal depth, as confirmed by geophysical data (Mattia et al., 2007).

Currently, the volcanic activity is limited to gas emissions at boiling temperature in the Favare, Cuddia Di Mida, and M. Gibele regions (south-central part of the island). Thermal waters enriched in $\mathrm{CO}_{2}$ are found along the coast in the northwest and southwest areas (Dongarrà et al., 1983), and other thermal springs and anomalous degassing areas are situated along the shoreline of the 'Specchio di Venere' Lake (Favara et al., 2001; Aiuppa et al., 2007). Water temperatures range 
from 20 to $90{ }^{\circ} \mathrm{C}$ with $\mathrm{pH}$ values from 6.1 to 9.3 (Dongarrà et al., 1983; Parello et al., 2000). These waters are chlorine dominated, and many thermal waters are rich in carbonate species due to the interaction with $\mathrm{CO}_{2}$ discharged from the magmatic system (Parello et al., 2000). The scenario mentioned above suggests that the water circulating in Pantelleria Island represents a mixture of $\mathrm{CO}_{2}$-rich thermal water, seawater, and meteoric water.

'Specchio di Venere' Lake is a saline endorheic basin formed within a calderic depression called 'Caldera Cinque Denti'. It is fed by several thermal springs and meteoric water. Aiuppa et al. (2007) excluded any direct implication of seawater in the lake, highlighting that the lake is sometimes stratified. Such stratification is unstable and of short duration (generally a few days); and changes in meteorological conditions (rain and/or wind) are able to mix the lake water which is only 13 m deep (Aiuppa et al., 2007). The existence of reducing conditions at the water-sediment interface at the bottom of the lake was recognized (Aiuppa et al., 2007), while isotopic analysis $\left(\delta \mathrm{D} ; \delta^{18} \mathrm{O}\right)$ in 'Specchio di Venere' Lake suggests the sustained evaporation of the water body (Dongarrà et al., 1983).

\section{Results}

\subsection{General aspects}

The chemical physical parameters and the major element concentrations of the investigated waters are reported in Table 1. Temperatures range between 26.8 and $54.6{ }^{\circ} \mathrm{C}$, Eh values span -245 to 162 $\mathrm{mV}, \mathrm{pH}$ values range between 6.0 and 9.0, and electrical conductivity values increase from 2 to 35 $\mathrm{mS} / \mathrm{cm}$. In the anion triangular plot (Fig. 2a), waters fall along the line connecting the seawater composition and the alkalinity vertex, suggesting a mixing process between seawater and water enriched in $\mathrm{CO}_{2}$. The waters from the top and the bottom of the lake show the same anionic composition. The cation triangular plot displays waters falling close to the $\mathrm{Na}-\mathrm{K}$ vertex ( $\mathrm{Na}$ is the dominant cation) with a low dispersion of samples towards the $\mathrm{Mg}$ and $\mathrm{Ca}$ vertices. The waters from the top and the bottom of the lake show relatively constant cation compositions (Fig. 2b). The 
$\mathrm{Na}-\mathrm{Cl}$ binary graph (Fig. 3) shows that almost all samples are characterized by $\mathrm{Na} / \mathrm{Cl}$ molar ratios higher than that in seawater. The excess of $\mathrm{Na}$ is due to the interaction process of the water with the Na-rich host rocks (Dongarrà et al., 1983). The chemical composition, pH, and electrical conductivity do not show a significant difference between the water samples collected in the shallowest part and at the bottom of 'Specchio di Venere' Lake, whereas Eh values are characterized by a variation from -31 (top) to $-245 \mathrm{mV}$ (bottom). Moreover, the physicochemical parameters of the water and the major elements have an almost constant concentration along the water column (Jácome Paz et al., 2016).

The $\mathrm{CO}_{2}$ dissolved in water ranges between 3 and $357 \mathrm{cc} \mathrm{L}^{-1}$ (Tab. 1), with values several orders of magnitude higher than the air saturated sea water (ASSW) $\left(0.24 \mathrm{cc} \mathrm{L}^{-1}\right.$ of $\left.\mathrm{CO}_{2}\right)$. A triangular plot of $\mathrm{CO}_{2}-\mathrm{N}_{2}-\mathrm{O}_{2}$ (Fig. 4) displays the waters aligned along the line connecting the $\mathrm{CO}_{2}$ vertex with the ASSW, showing the $\mathrm{CO}_{2}$-water interaction in different proportions (Inguaggiato et al., 2011, 2013) with some depletion in $\mathrm{O}_{2}$.

Results of the PHREEQC simulation showed that the waters from wells and springs are oversaturated in comparison with the carbonate minerals and the Fe-oxyhydroxides, except for those in the Daietti well which is undersaturated in carbonate minerals and Polla 3 that is undersaturated with respect to Fe-oxyhydroxides (Tab. 2). Furthermore, the investigated waters are all saturated in amorphous silica. Further investigations were carried out with SEM-EDS analysis into the nature of the SPM (Fig. 5a) from the lake water and Polla 3 (thermal spring feeding the lake). The Fe-oxyhydroxides (Fig. 5b-c) and phyllosilicates (Fig. 5d-e) were recognized as SPM in the shallowest water layer of the lake. Amorphous silica was recognized in the Polla 3 sample (Fig. 5f).

\subsection{REE, Zr, and Hf}

The total amount of REE ranges between 2.77 and $12.07 \mathrm{nmol} \mathrm{L}{ }^{-1}$, with the highest value found in the lake water (Tab. 3). A strong relationship between the total REE dissolved in water and the $\mathrm{pH}$ 
values was recognized in several aqueous environments, highlighting the important role of $\mathrm{pH}$ for the REE mobility and the total REE concentration (Lewis et al., 1998; Michard, 1989; Inguaggiato et al., 2015). In the investigated waters, the relationship between REE and pH values is not very clear, however. The total REE content is not simply correlated to the total dissolved solids (TDS), indicating that the REE concentration in the investigated waters is not related to the salinity. The lack of a clear relationship between the concentration of REE and the physicochemical parameters was also recognized in $\mathrm{CO}_{2}$-rich waters ( $\mathrm{pH}$ 6-7) investigated in the Massif Central (France) (Négrel et al., 2000).

The REE normalized to the PAAS show LREE depleted patterns (Fig. 6) with Ce and Eu anomalies, that is, $\mathrm{Ce} / \mathrm{Ce} *$ values from 0.27 to 1.98 and $\mathrm{Eu} / \mathrm{Eu}^{*}$ values from 0.95 to 1.53 . The water samples collected from the top and the bottom of 'Specchio di Venere' Lake show REE patterns with a concave shape facing downward and a relatively constant REE distribution (Fig. 6). The REE patterns display HREE enrichments with (LREE/HREE) $)_{\mathrm{N}}$ ratios ranging from 0.03 to 0.20 , whereas $(\mathrm{MREE} / \mathrm{HREE})_{\mathrm{N}}$ ratios range between 0.26 and 1.53 (Fig. 7). The MREE enrichments were recognized in the 'Specchio di Venere' Lake water samples that are the only samples with $(\mathrm{MREE} / \mathrm{HREE})_{\mathrm{N}}$ ratios $>1$ (Fig. 7).

The amount of $\mathrm{Y}$ and Ho dissolved in the waters ranges from 0.97 to $5.64 \mathrm{nmol} \mathrm{L}^{-1}$ and from 0.022 to $0.15 \mathrm{nmol} \mathrm{L}^{-1}$, respectively, with $\mathrm{Y} / \mathrm{Ho}$ molar ratios ranging between 35.4 and 77.9 . The amount of $\mathrm{Zr}$ and $\mathrm{Hf}$ dissolved in the waters ranges from 0.62 to $23.1 \mathrm{nmol} \mathrm{L}^{-1}$ and from 0.003 and 0.30 nmol L $\mathrm{L}^{-1}$, respectively, with $\mathrm{Zr} / \mathrm{Hf}$ ratios between 76.3 and 299. The highest amounts of $\mathrm{Y}, \mathrm{Ho}, \mathrm{Zr}$, and Hf were found in the lake waters without significant differences between the shallow and deep samples and characterized by the lowest $\mathrm{Y} / \mathrm{Ho}$ and $\mathrm{Zr} / \mathrm{Hf}$ ratios of 35.4 and 76.3 , respectively.

\section{Discussion}

\subsection{Aqueous speciation}


Experimental measurements and theoretical computations were carried out regarding the complexation constants of the REE with inorganic ligands (Millero et al., 1992; Wood, 1990). Carbonate ligands show a progressive increase in the REE complexes stability constants from LREE to HREE. The REE complex constants with carbonate ligands are higher than the weak chloride complexes (Wood, 1990 and references therein). Moreover, Millero (1992) shows that the dominant complexes in seawater are carbonate ligands, with a secondary role for chloride complexes. Négrel et al. (2000) calculated the dissolved REE speciation in $\mathrm{Na}-\mathrm{HCO}_{3}$ bearing fluids of the Massif Central, recognizing $\mathrm{HCO}_{3}{ }^{-}$and particularly $\mathrm{CO}_{3}{ }^{-2}$ as the main ligands of the REE complexes. The REE aqueous speciation calculated by PHREEQC indicates that the free ions $\left(\mathrm{REE}^{+3}\right)$ are always a small fraction compared to the REE complexes (Fig. 8). The results show the main role played by the carbonate complexes $\left[\operatorname{REE}\left(\mathrm{CO}_{3}\right)_{2}\right]^{-}$and $[\mathrm{REECO}]^{+}$, whereas $[\mathrm{REEF}]^{+2}$ became significant in water with higher fluorine contents, including water from Gadir, La Vela, and Polla 3 (Fig. 8). [REECl $]^{+2}$ and $\left[\mathrm{REESO}_{4}\right]^{+}$are negligible with respect to the other complexes. Moreover, the speciation of the lake water from the top and the bottom does not show significant differences, and $\left[\mathrm{REE}\left(\mathrm{CO}_{3}\right)_{2}\right]$ ' dominates the speciation in 'Specchio di Venere' Lake with pH 9.0 (Fig. 8).

\subsection{REE behaviour in springs and wells}

The distribution of REE in waters circulating in Pantelleria Island is the result of the mixing of a marine component, $\mathrm{CO}_{2}$-rich fluids, and meteoric water, as indicated by the major elements (Dongarrà et al., 1983; Azzaro et al., 1983). The water samples from springs and wells are characterized by similar patterns with the exception of $\mathrm{Ce}$ and $\mathrm{Eu}$, suggesting one or more geochemical processes in common. The REE dissolved in the seawater of the Strait of Sicily (Censi et al., 2004) were normalized to the PAAS to compare the distribution of REE with the waters circulating in Pantelleria. The investigated waters display REE patterns with the same trend as the average Strait of Sicily seawater; while the REE amount dissolved in the Pantelleria waters is about 
one order of magnitude higher with respect to seawater (Fig. 6). This evidence indicates that the marine contamination is not able to change the REE distribution in the studied waters significantly. Therefore, the main processes responsible for REE distribution in water are: 1) the interaction with the host rocks, 2) the precipitation of authigenic minerals, and 3) the REE complexation as a function of the anionic composition.

In order to compare the waters with the host rocks, the REE concentrations of the local magmatic rocks (White et al., 2009) were normalized to the PAAS. The normalized patterns of the local rocks are flat in shape, showing positive Eu anomalies in basalts and occasionally in trachytes. In more evolved tuffs and pantellerites, Eu anomalies became negative (White et al., 2009). The positive Eu anomalies observed in the studied waters (Fig. 9) are the consequence of the interaction process between the water circulating in the hydrothermal system within the less evolved rocks, such as Carich feldspar. Since pantellerite is formed after the fractional crystallization of Ca-rich feldspar from the trachyte magma, the presence and the amplitude of the Eu anomaly can be considered as a geochemical tracer of the water-rock interaction with the less evolved rocks- the only ones with a positive Eu anomaly.

Comparing the REE patterns of Pantelleria waters with other studies on $\mathrm{CO}_{2}$-rich groundwater in different regions of the world, similar features are found with HREE enriched waters (Michard, 1989; Négrel et al., 2000; Choi et al., 2009; Jianfei et el., 2014). This evidence suggests that the distribution of $\mathrm{REE}$ in $\mathrm{CO}_{2}$-rich waters does not depend only on the source rock, but on geochemical processes as well.

Choi et al. (2009) investigated the REE in $\mathrm{CO}_{2}$-rich waters in the Kangwon district (South Korea) showing HREE enrichments with respect to LREE in the $\mathrm{Na}-\mathrm{HCO}_{3}$ water. Moreover, they studied the distribution of REE in carbonate minerals formed by the same waters, without finding significant changes in the REE distribution between the residual waters obtained after the filtration of solid phases and the original waters. The precipitation of the carbonate solid phases occurs in Pantelleria waters (as suggested by PHREEQC calculation); but it should change only the REE 
amount dissolved in the water and not their distribution. The explanation of the lack of REE fractionation during the precipitation of carbonates has been attributed to the main complexation of REE with carbonate ligands causing the preferential co-precipitation with carbonates and resulting in HREE enrichment compared to LREE, both in the water and in the precipitated carbonates (Choi et al., 2009; Feng et al., 2014 and references therein;). The distribution of REE in the investigated waters is the result of carbonate-REE complexation driving the REE distribution in $\mathrm{CO}_{2}$-rich water.

\subsection{Ce anomaly}

Cerium is sensitive to redox changes and easily removed from solution as $\mathrm{CeO}_{2}$ and/or by adsorption onto Mn- and Fe-oxyhydroxide under oxidizing conditions (Bau, 1999; Seto and Tsaku, 2008; Bau and Koschinsky, 2009 and references therein). Figure 10 shows an inverse trend between the $\mathrm{Ce}$ anomaly and the Eh values. Almost all waters are saturated or oversaturated in $\mathrm{Fe}$ oxyhydroxides, except Polla 3, where lower $\mathrm{pH}(6.4)$ and $\mathrm{Eh}(-107 \mathrm{mV})$ values were measured. Polla 3 shows a positive anomaly of Ce (1.3), in agreement with the lack of Fe mineral saturation, as shown by the PHREEQC simulation. Buvira Rizzo is the only water sample showing a different behaviour of $\mathrm{Ce}$, with a positive Ce anomaly and positive Eh value (Fig. 10). Buvira Rizzo is an unexploited old hand-dug well about $3 \mathrm{~m}$ deep, where a high amount of organic matter was recognized (D'Alessandro personal communication). The Ce concentration in the water could be controlled by the amount of dissolved organic carbon (DOC). When DOC was higher than $10 \mathrm{mg} / \mathrm{l}$, no negative Ce anomaly was recognized in several waters (Seto and Tsaku, 2008 and references therein). Moreover, a higher amount of organic compounds could promote the dissolution of Fe, increasing the $\mathrm{Ce}$ concentration in waters and justifying the positive $\mathrm{Ce}$ anomaly in the Buvira Rizzo water.

A strong positive Ce anomaly was found in the lake water, quite different from the hydrothermal waters. Considering that $\mathrm{Ce}$ is enriched in the desert varnish, the addition of $\mathrm{Ce}$ is justified by the contribution of atmospheric fallout from the nearby Sahara Desert. 


\subsection{Y/Ho and $\mathrm{Zr} / \mathrm{Hf}$ fractionation in spring and wells}

The investigated waters should have molar $\mathrm{Y} / \mathrm{Ho}$ and $\mathrm{Zr} / \mathrm{Hf}$ close to the host rocks, that have ratios of 49 and 80, respectively (White et al., 2009). The Y/Ho and $\mathrm{Zr} / \mathrm{Hf}$ values found in the investigated springs and wells show values very different from the local rocks, suggesting fractionation of these element couples (Fig. 11). Assuming that these elements are released into waters with Y/Ho and $\mathrm{Zr} / \mathrm{Hf}$ ratios close to the source rocks, secondary processes (such as scavenging into and/or onto the secondary minerals) would explain the fractionation of the twin pairs in the investigated waters. The processes responsible for fractionating the $\mathrm{Zr}$-Hf pairs are not well known, and even today no experiment has been carried out in a laboratory. Contrary to $\mathrm{Y}$ and $\mathrm{Ho}, \mathrm{Zr}$ and $\mathrm{Hf}$ are not complexed by carbonate species. Byrne (2002) shows that $\mathrm{Zr}$ and $\mathrm{Hf}$ are mainly complexed by hydroxyl groups in the $\mathrm{pH}$ range between 6 and 8 forming $\mathrm{Zr}, \mathrm{Hf}(\mathrm{OH})_{4}$ and $\mathrm{Zr}, \mathrm{Hf}(\mathrm{OH})_{5}{ }^{-}$. Qu et al. (2009) recognized the fractionation of $\mathrm{Y}$ and Ho during the precipitation of calcite and aragonite with enhanced removal of Ho with respect to $\mathrm{Y}$, due to the different electronic configurations of these elements. Moreover, several studies have shown the ability of a Fe/Mn-oxyhydroxide precipitation to fractionate Y-Ho and Zr-Hf. Inguaggiato et al. (2015) investigated the Y/Ho and $\mathrm{Zr} / \mathrm{Hf}$ ratios in the Nevado del Ruiz volcanic waters (Colombia), showing super-chondritic values in waters with pH 6 to 8.8, where the precipitation of Fe- and Al-oxyhydroxides occurs. Schmidt et al. (2014) investigated $\mathrm{Zr} / \mathrm{Hf}$ ratios in hydrogenetic ferromanganese crusts in seawater, showing strong enrichment compared to the average crust and highlighting an enhanced Hf removal with respect to $\mathrm{Zr}$. Moreover, the preferential removal of $\mathrm{Hf}$ with respect to $\mathrm{Zr}$ in a $\mathrm{SiO}_{2}$ precipitated phase was found (Firdaus et al., 2011 and references therein). Censi et al. (2015) investigated a microsystem occurring in the southwestern sector of 'Specchio di Venere' Lake, identifying higher surface reactivity of $\mathrm{Hf}$ than $\mathrm{Zr}$ in siliceous stromatolites and microbial mats.

The PHREEQC calculations revealed that the investigated waters are oversaturated in Fe/Aloxyhydroxides, carbonate minerals, and saturated amorphous $\mathrm{SiO}_{2}$. Moreover, amorphous $\mathrm{SiO}_{2}$ was 
found in the Polla 3 thermal spring by SEM-EDS analysis. Considering the geochemical processes mentioned above, the precipitation of authigenic minerals and the consequent interaction between the elements dissolved in waters and the solid phases can be considered the processes responsible for decoupling the $\mathrm{Y} / \mathrm{Ho}$ and $\mathrm{Zr} / \mathrm{Hf}$ ratios in springs and wells which show higher values (up to 299) than in the source rocks.

\subsection{Source of REE, Zr, and Hf in 'Specchio di Venere' Lake}

It is important to determine the main process controlling the geochemistry of REE, $\mathrm{Zr}$, and $\mathrm{Hf}$ in 'Specchio di Venere' Lake water. The geochemistry of REE, Zr, and Hf in alkaline lakes is, in general, poorly documented. Johannesson and Lyons (1994) investigated the Mono Lake waters, recognizing a LREE depleted pattern and highlighting the importance of carbonate complexes for

the REE distribution. A similar reasoning could be applied to 'Specchio di Venere' Lake with its LREE depleted pattern in the surface waters. We consider here an alternate source, the dust from the nearby Sahara Desert.

The atmospheric fallout delivered by the Sahara Desert (North Africa) inevitably involves Pantelleria Island, located $70 \mathrm{~km}$ east of the Tunisian coast. The water of the 'Specchio di Venere' Lake shows MREE enrichment not recognized in the other waters collected from the springs and wells in Pantelleria Island (Fig. 6). In particular, the lake water body has REE amounts higher than the other waters, including the Polla 3 thermal spring feeding the lake along the shoreline. This evidence suggests an external process adding REE to the lake water and increasing the relative abundance of MREE with respect to LREE and HREE.

Several studies have been carried out in order to evaluate the role of the atmospheric fallout in the REE composition of seawater. The influence of aeolian dust from the Asian continent affects the composition of REE in the western Pacific Ocean (Greaves et al., 1999). Graves et al. (1991) showed higher REE concentrations in Mediterranean Sea water with respect to the Atlantic Ocean, suggesting the aeolian dust as the REE source (Greaves et al., 1991 and references therein). 
Moreover, the Mediterranean outflow was recognized to produce anomalies in the Atlantic seawater by the mixing of different seawater masses (Greaves et al., 1991).

In arid environments, the formation of a desert varnish, mainly composed of clay minerals and Feand Mn-oxyhydroxide coatings, occurs on rock surfaces (Thiagarajan and Lee, 2004; Goldsmith et al. 2014). The desert varnish is characterized by an REE pattern similar to the settling dust proposed here as source material (Fig. 12) (Goldsmith et al., 2014 and references therein). Moreover, the solid phases mentioned above are enriched in REE (especially MREE), showing a pattern similar to that recognized in the top and the bottom waters of 'Specchio di Venere' Lake which is characterized by MREE/HREE >1 (Figg. 7, 12). Greaves et al. (1994) carried out a laboratory experiment evaluating the dissolution effect of a marine aerosol of Saharan origin into shallow seawater collected in the Indian Ocean and showed a higher solubility of MREE into seawater with respect to LREE and HREE. The distribution of HREE in 'Specchio di Venere' Lake is very similar to that found in Polla 3 (thermal spring), while the MREE are strongly enriched only in the lake. The HREE enrichment pattern of the lake water is mainly inherited from the hydrothermal input due to the carbonate-REE complexation effect, while the atmospheric fallout contribution is responsible for the MREE enrichment (Fig. 12).

Y/Ho and Zr/Hf ratios in 'Specchio di Venere' Lake are close to the values recognized in the desert varnish (average $\mathrm{Y} / \mathrm{Ho}$ and $\mathrm{Zr} / \mathrm{Hf}$ ratios of 38.0 and 73.4, respectively). The reducing condition and the higher $\mathrm{pH}$ of the lake water as compared to seawater, certainly enhances the dissolution of the Fe-oxyhydroxides coating the Saharan fallout. Considering the evidence shown here coupled with the presence of Fe-oxyhydroxide and phyllosilicates as SPM in the shallowest water layer (Fig. 5), we suggest that the dissolution of the atmospheric fallout from the Sahara Desert and its surrounding area can change the chemical composition of water. Such changes are reflected in the increase of $\mathrm{Zr}$, Hf, and REE concentrations, in the formation of a Ce anomaly, in the 'bulge effect' in the REE pattern, and in the $\mathrm{Y} / \mathrm{Ho}$ and $\mathrm{Zr} / \mathrm{Hf}$ ratios with a desert varnish signature. 


\section{Concluding remarks}

The $\mathrm{CO}_{2}$-rich waters in Pantelleria Island have variable amounts of REE, with similar PAAS normalized REE patterns with LREE depletion. The REE distribution does not depend only on the source rocks; but mainly reflects the distribution of REE with carbonate complexes, as recognized elsewhere. Positive and negative $\mathrm{Ce}$ anomalies were recognized as a function of the redox conditions. The negative anomalies are due to the co-precipitation onto the surface of the $\mathrm{Fe}$ oxhydroxides in water with positive Eh values. The positive Eu anomaly proved to be a useful tool in the evaluation of the water-rock interaction with less evolved hosting rocks that were also characterized by a positive Eu anomaly. The ratios $\mathrm{Y} / \mathrm{Ho}$ and $\mathrm{Zr} / \mathrm{Hf}$ in springs and wells are higher compared to those in the local rock, evidencing fractionation processes in the aqueous system. The decoupling of these elements is due to their different affinity for the secondary solid phases (carbonate minerals, Fe-oxyhydroxides, and amorphous silica) precipitating from these waters.

The REE, Zr, and Hf in the 'Specchio di Venere' Lake have the highest concentrations recognized in the Pantelleria hydrothermal system. Similar distributions of REE normalized to PAAS were found in both the top and the bottom of the lake, showing a pattern comparable to that identified in the desert varnish and the settling dust, with MREE enrichment and a positive Ce anomaly. Moreover, $\mathrm{Y} / \mathrm{Ho}$ and $\mathrm{Zr} / \mathrm{Hf}$ ratios in the lake water show values comparable to those found in the desert varnish. The REE coupled with the $\mathrm{Y} / \mathrm{Ho}$ and $\mathrm{Zr} / \mathrm{Hf}$ ratios proved to be useful geochemical tracers for identifying the atmospheric particulate contribution to the water body.

\section{Acknowledgements}

We thank Dr David R. Hilton for handling the editorial functions and Dr Johan C. Varekamp and an anonymous reviewer for constructive comments that improved the quality and the clarity of the manuscript. 
This work is part of the doctoral thesis of the first author and was supported by the Università degli Studi di Palermo, the Université Pierre et Marie Curie, the Istituto Nazionale di Geofisica e Vulcanologia (Palermo), and the Università Italo-Francese.

\section{References}

Aiuppa, A., D’Alessandro, W., Gurrieri, S., Madonia, P., Parello, F., 2007. Hydrologic and geochemical survey of the lake "Specchio di Venere" (Pantelleria island, Southern Italy). Environ. Geol. 53, 903-913, DOI 10.1007/s00254-007-0702-1.

Alibo, D.S., Nozaki, Y., 1999. Rare earth elements in seawater: particle association, shalenormalization, and Ce oxidation. Geochim. Cosmochim. Acta 63, 363-372.

Ayres, G. 2012. Behaviour of the REE during water rock interaction and alteration processes in volcanic lake systems. Ms thesis, Utrecht University, The Netherlands, 1-108.

Azzaro, E., Badalamenti, F., Dongarrà, G., Hauser, S., 1983. Geochemical and mineralogical studies of lake Specchio di Venere, Pantelleria island, Italy. Chem. Geol. 40, 149-165

Bau, M., 1996. Controls on the fractionation of isovalent trace elements in magmatic and aqueous systems: Evidence from $\mathrm{Y} / \mathrm{Ho}, \mathrm{Zr} / \mathrm{Hf}$, and lanthanide tetrad effect. Contrib. Mineral. Petrol. 123, 323-333.

Bau, M., 1999. Scavenging of dissolved yttrium and rare earths by precipitating iron oxyhydroxide: Experimental evidence for Ce oxidation, Y-Ho fractionation, and lanthanide tetrad effect. Geochim. Cosmochim. Acta 63, 67-77.

Bau, M., Dulski, P., 1999. Comparing yttrium and rare earth in hydrothermal fluids from the MidAtlantic Ridge: implications for $\mathrm{Y}$ and REE behaviour during near-vent mixing and for the Y/Horatio of Proterozoic Seawater. Chem. Geol. 155, 77-90.

Bau, M., Koschinsky, A., 2009. Oxidative scavenging of cerium on hydrous Fe oxide: Evidence from the distribution of rare earth elements and yttrium between $\mathrm{Fe}$ oxides and $\mathrm{Mn}$ oxides in hydrogenetic ferromanganese crusts. Geochem. J. 43, 37-47. 
Byrne, R.H., 2002. Inorganic speciation of dissolved elements in seawater: The influence of $\mathrm{pH}$ on concentration ratios. Geochem. Transact. 3, 11-16.

Capasso, G., Inguaggiato, S., 1998. A simple method for the determination of dissolved gases in natural waters. An application to thermal waters from Vulcano Island. Appl. Geochem. 13, 631642.

Censi, P., Mazzola, S., Sprovieri, M., Bonanno, A., Patti, B., Punturo, R., Spoto, S. E., Saiano, F., 2004. Rare earth elements distribution in seawater and suspended particulate of the central Mediterranean Sea. Chem. Ecol. 20, 323-343.

Censi, P., Zuddas, P., Larocca, D., Saiano, F., Placenti, F., Bonanno, A., 2007. Recognition of water masses according to geochemical signatures in the Central Mediterranean sea: Y/Ho ratio and rare earth element behaviour. Chem. Ecol. 23(2), 139-155.

Censi, P., Cangemi, M., Brusca, L., Madonia, P., Saiano, F., Zuddas, P., 2015. The behavior of rareearth elements, $\mathrm{Zr}$ and $\mathrm{Hf}$ during biologically-mediated deposition of silica-stromatolites and carbonate-rich microbial mats. Gondwana Res. 27, 209-215.

Choi, H., Yun, S., Koh, Y., Mayer, B., Park, S., Hutcheon, I., 2009. Geochemical behavior of rare earth elements during the evolution of $\mathrm{CO}_{2}$-rich groundwater: A study from the Kagwon distrivt, South Korea. Chem. Geol. 262, 318-327.

Civetta, L., Cornette, Y., Gillot, P.Y., Orsi, G., 1988. The eruptive history of Pantelleria (Sicily Channel) in the last $50 \mathrm{ka}$. Bull. Volcanol. 50, 47-57.

Colvin, A., Rose, W. I., Varekamp, J. C., Palma, J. L., Escobar, D., Gutierrez, E., Montalvo, F., Maclean, A., 2013. Crater lake evolution at Santa Ana Volcano (El Salvador) following the 2005 eruption. Geol. Soc. Am. Spec. Paper 498, 23-44.

D’Alessandro, W., Bellomo, S., Brusca, L., Fiebig, J., Longo, M., Martelli, M., Pecoraino, G., Salerno, F., 2009. Hydrothermal methane fluxes from the soil at Pantelleria island (Italy). J. Volcanol. Geotherm. Res. 187, 147-157

Dongarrà, G., Hauser, S., Alaimo, R., Carapezza, M., Tonani, F., 1983. Hot waters on Pantelleria 
island. Geochemical features and preliminary geothermal investigation Geotherm. 12, 49-63.

Favara, R., Giammanco, S., Inguaggiato S., Pecoraino, G., 2001. Preliminary estimate of $\mathrm{C}_{\mathrm{O} 2}$ output from Pantelleria island volcano (Sicily, Italy): evidence of active mantle degassing. Appl. Geochem. 16, 883-894.

Feng, J.L., Zhao, Z.H., Chen, F., Hi, P.H., 2014. Rare earth elements in sinters from the geothermal waters (hot spring) on the Tibetan Plateau, China. J. Volcanol. Geotherm. Res. 287, 1-11.

Firdaus, M.L., Minami, T., Norisuye, K., Sohrin, Y., 2011. Strong elemental fractionation of Zr-Hf and Nb-Ta across the Pacific Ocean. Nat. Geosci. 4, 227-230.

Frank, M., 2011. Oceanography: Chemical twins, separated. Nat. Geosci. 4, 220-221.

Godfrey, L.V., Field, M.P., 2008. Estuarine distributions of Zr, Hf, and Ag in the Hudson River and the implications for their continental and anthropogenic sources to seawater. Geochem. Geophys. Geosyst. 9, 359-370.

Godfrey, L.V., Zimmermann, B., Lee, D.C., King, R.L., Vervoort, J.D., Sherrell, R.M., Halliday, A.N., 2009. Hafnium and neodymium isotope variations in NE Atlantic seawater. Geochem. Geophys. Geosyst. 10(8), 1-13.

Goldsmith, Y., Stein, M., Enzel, Y., 2014. From dust to varnish: Geochemical constraints on rock varnish formation in the Negev Desert, Israel. Geochim. Cosmochim. Acta 126, 97-111.

Greaves, M.J., Rudnicki, M., Elderfield, H., 1991. Rare earth elements in the Mediterranean Sea and mixing in the Mediterranean outflow. Earth Planet. Sci. Lett. 103, 169-181.

Greaves, M.J., Statham, P.J., Elderfield, H., 1994. Rare earth element mobilization from marine atmospheric dust into seawater. Mar. Chem. 46, 255-260.

Greaves, M.J., Elderfield, H., Sholkovitz, E.R., 1999. Aeolian sources of rare earth elements to the Western Pacific Ocean. Mar. Chem. 68, 31-38Jianfei, Y., Xumei, M., Yanxin, W., Zhide, D., Leihui, H., 2013. Geochemistry of rare-earth elements in shallow groundwater, northeastern Guangdong Province, China. Chin. J. Geochem. 33, 53-64. 
Inguaggiato, S., Calderone, L., Inguaggiato, C., Morici, S., Vita, F., 2011. Dissolved $\mathrm{CO}_{2}$ in natural waters: development of an automated monitoring system and first application to Stromboli volcano (Italy). Ann. Geophys., 54(2), 209-218.

Inguaggiato, S., Jacome Paz, M.P., Mazot, A., Delgado Granados, H., Inguaggiato, C., Vita , F., 2013. $\mathrm{CO}_{2}$ output discharged from Stromboli Island (Italy). Chem. Geol. 339, 52-60. doi: 10.1016/j.chemgeo.2012.10.008

Inguaggiato, C., Censi, P., Zuddas, P., Londoño, J., M., Chacón, Z., Alzate, D, Brusca, L., D'Alessandro, W. 2015. Geochemistry of REE, $\mathrm{Zr}$ and $\mathrm{Hf}$ in a wide range of $\mathrm{pH}$ and water composition: The Nevado del Ruiz volcano-hydrothermal system (Colombia). Chem. Geol. 417, 125-133. doi: 10.4401/ag-5180

Jácome Paz, M. P., Inguaggiato S., Taran, Y., Vita, F., Pecoraino, G., 2016. Carbon dioxide emissions from Specchio di Venere, Pantelleria, Italy. Bull. Volcanol. 78(29), pp 1-12. Doi: $10.1007 / \mathrm{s} 00445-016-1023-6$

Johannesson, K.H., Lyons, B.W., 1994. The rare earth elements geochemistry of Mono Lake water and the importance of carbonate complexing. Limnol. Oceanogr. 39(5), 1141-1154.

Lewis, A.J., Komninou, A., Yardley, B.W., Palmer, M.R., 1998. Rare earth element speciation in geothermal fluids from Yellowstone National Park, Wyoming, USA. Geochim. Cosmochim. Acta $62,657-663$.

Mattia, M., Bonaccorso, A., Guglielmino, F., 2007. Ground deformations in the Island of Pantelleria (Italy): Insights into $\square$ the dynamic of the current intereruptive period. J. Geophys. Res. $112,1-11$

Mahood, G.A., Hildreth, W., 1986. Geology of the perakaline volcano at Pantelleria, Strait of Sicily. Bull. Volcanol. 48, 143-172.

Michard, A., 1989. Rare earth element systematics in hydrothermal fluids. Geochim. Cosmochim. Acta 53, 745-750. 
Millero, F.J., 1992. Stability-Constants for the Formation of Rare-Earth Inorganic Complexes as a Function of Ionic-Strength. Geochim. Cosmochim. Acta 56, 3123-3132.

Négrel, Ph., Guerrot, C., Cocherie, A., Azaroual, A., Brash, M., Fouillac, Ch., 2000. Rare earth elements, neodymium and strontium isotopic systematics in mineral waters: evidence from the Massif Central, France. Appl. Geochem. 15, 1345-1367.

Olivarez, A.M., Owen, R.M., 1989. REE/Fe variations in hydrothermal sediments: Implications for the REE content of seawater: Geochim. Cosmochim. Acta 53, 757-762.

Parello, F., Allard, P., D’Alessandro, W., Federico, C., Jean-Baptiste, P., Catani, O., 2000. Isotope geochemistry of Pantelleria volcanic fluids, Sicily Channel rift: a mantle volatile end-member for volcanism in southern Europe. Earth Planet. Sci. Lett. 180, 325- 339

Parkhurst, D.L., Appelo, C.A.J., 2010. User's Guide to PHREEQC (Version 2.17.5)-A Computer program for Speciation, Batch- Reaction, One-Dimensional Transport and Inverse Geochemical Calculations.

Piper, D.Z., Bau, M., 2013. Normalized Rare Earth Elements in Water, Sediments, and Wine: Identifying Sources and Environmental Redox Conditions. Am. J. Analyt. Chem. 4, 69-83.

Qu, C.L., Liu, G., Zhao, Y.F., 2009. Experimental study on the fractionation of yttrium from holmium during the coprecipitation with calcium carbonates in seawater solutions. Geochem. J. 43, $403-414$

Raso, M., Censi, P., Saiano, F., 2013. Simultaneous determinations of zirconium, hafnium, yttrium and lanthanides in seawater according to a co-precipitation technique onto iron-hydroxide. Talanta $116,1085-1090$.

Ruberti, E., Castorina, F., Censi, P., Comin-Chiaramonti, P., Gomes, C.B., Antonini, P., Andrade, F.R.D., 2002. The geochemistry of the Barra do Itapirapuã carbonatite (Ponta Grossa Arch, Brazil): amultiple stockwork. J. S. Am. Earth Sci. 15 (2), 215-228. 
Schmidt, K., Bau, M., Hein J. R., Koschinsky, A., 2014. Fractionation of the geochemical twins Zr-

Hf and $\mathrm{Nb}$-Ta during scavenging from seawater by hydrogenetic ferromanganese crusts. Geochim. Cosmochim. Acta 140, 468-487.

Seto, M., Tsaku, A., 2008. Chemical condition for the appearance of a negative Ce anomaly in stream waters and groundwaters. Geochem. J. 42, 371-38.

Taylor, S.R., McLennan, S., 1985. The Continental Crust: Its Composition and Evolution. Blackwell, Oxford, 312 pp.

Thiagarajan, N., Lee, C.T.A., 2004. Trace-element evidence for the origin of desert varnish by direct aqueous atmospheric deposition, Earth Planet. Sci. Lett. 224(1-2), 131-141.

Varekamp, J.C., 2015. The Chemical Composition and Evolution of Volcanic Lakes. In: Rouwet, D., Christenson, B., Tassi, F., Vandemeulebrouck, J. eds, Volcanic Lakes, 93-123.

Wang, Z., Liu C., Zhu, Z., 2013. Rare earth element geochemistry of waters and suspended particles in alkaline lakes using extraction and sequential chemical methods. Geochem. J. 47, 639649.

White J.C., Parker D.F., Minghua R., 2009. The origin of trachyte and pantellerite from Pantelleria, Italy: Insights from major element, trace element, and thermodynamic modelling. J. Volcanol. Geotherm. Res. 189, 33-55.

Wood, S.A., 1990. The aqueous geochemistry of the rare-earth elements and yttrium 1. Review of available low-temperature data for inorganic complexes and the inorganic REE speciation of natural waters. Chem. Geol. 82, 159-186.

Wood, S.A., 2003. The geochemistry of Rare Earth Elements and Yttrium in Geothermal Waters. Society of Economic Geologists Special Publication 10, 133-158.

\section{Figure captions}

Figure 1- Location map of the study area and of the sampling sites (modified after Mattia et al., 2007 and D'Alessandro et al., 2009) 
Figure 2- a) Triangular plot of major anions dissolved in waters. b) Triangular plot of major cations dissolved in waters.

Figure 3- The binary graph $(\mathrm{Na}$ vs. $\mathrm{Cl}$ ) shows higher $\mathrm{Na} / \mathrm{Cl}$ molar ratios with respect to the $\mathrm{Na} / \mathrm{Cl}$ molar ratio in seawater (dashed line). Na enrichments in waters are due to the water-rock interaction with the Na-alkaline hosting rock.

Figure 4- Triangular plot, relative abundance of $\mathrm{CO}_{2}, \mathrm{~N}_{2}$ and $\mathrm{O}_{2}$ dissolved in waters. The ASSW (air saturated seawater) value is reported for comparison. The dashed line represents the theoretical mixing between air dominated system and $\mathrm{CO}_{2}$-rich fluids.

Figure 5- Nature of suspended particulates in "Specchio di Venere" lake water and Polla 3 thermalspring feeding the lake [a]. Fe-oxyhydroxides [b] and phyllosilicates [d] from the shallowest water layer, as recognised by X-ray spectra [b] and [e], respectively. On the contrary, suspended particulates from the hydrothermal Polla 3 mainly consist of amorphous silica [f] as indicated by the reported x-ray maps for oxygen and silicon.

Figure 6- REE dissolved in waters normalised to the PAAS. The average seawater (by Censi et al., 2007) was plotted for comparison.

Figure 7- $(\mathrm{LREE} / \mathrm{HREE})_{\mathrm{N}}$ vs. $(\mathrm{MREE} / \mathrm{HREE})_{\mathrm{N}}$ showing values $<1$, except lake waters characterized by $(\mathrm{MREE} / \mathrm{HREE})_{\mathrm{N}}$ ratios $>1$. The seawater is reported for comparison.

Figure 8- Relative abundance (percentage) of the REE complexes in the investigated waters. REE aqueous speciation was performed with Phreeqc software (LLNL database).

Figure 9- No correlation was found between Eu and Ce anomalies, showing a different chemical behaviour. Positive Eu anomalies identify the interaction of waters with the less evolved hosting rocks.

Figure $10-\mathrm{Ce} / \mathrm{Ce}^{*}$ displays to be function of the Eh values, showing negative anomalies increasing the Eh values. Buvira Rizzo sample has an anomalous behaviour, probably due to the higher organic carbon concentration that enhanced the stability of $\mathrm{Ce}$ in the dissolved phase. The highest 
values of Ce anomalies are caused by the interaction of water with the atmospheric fallout enriched in Ce.

Figure 11- Changes of $\mathrm{Y} / \mathrm{Ho}$ and $\mathrm{Zr} / \mathrm{Hf}$ molar ratios in waters. The coloured band in the graph represents the range of $\mathrm{Y} / \mathrm{Ho}$ and $\mathrm{Zr} / \mathrm{Hf}$ ratios in desert varnish (Thiagarajan et al., 2004).

Figure 12- PAAS-normalised REE in lake waters (from top and bottom), Polla 3, average desert varnish and settling dust (values from: Thiagarajan and Aeolus Lee, 2004; Goldsmith et al., 2014). The arrows highlight the MREE and Ce contribution of desert dust. 


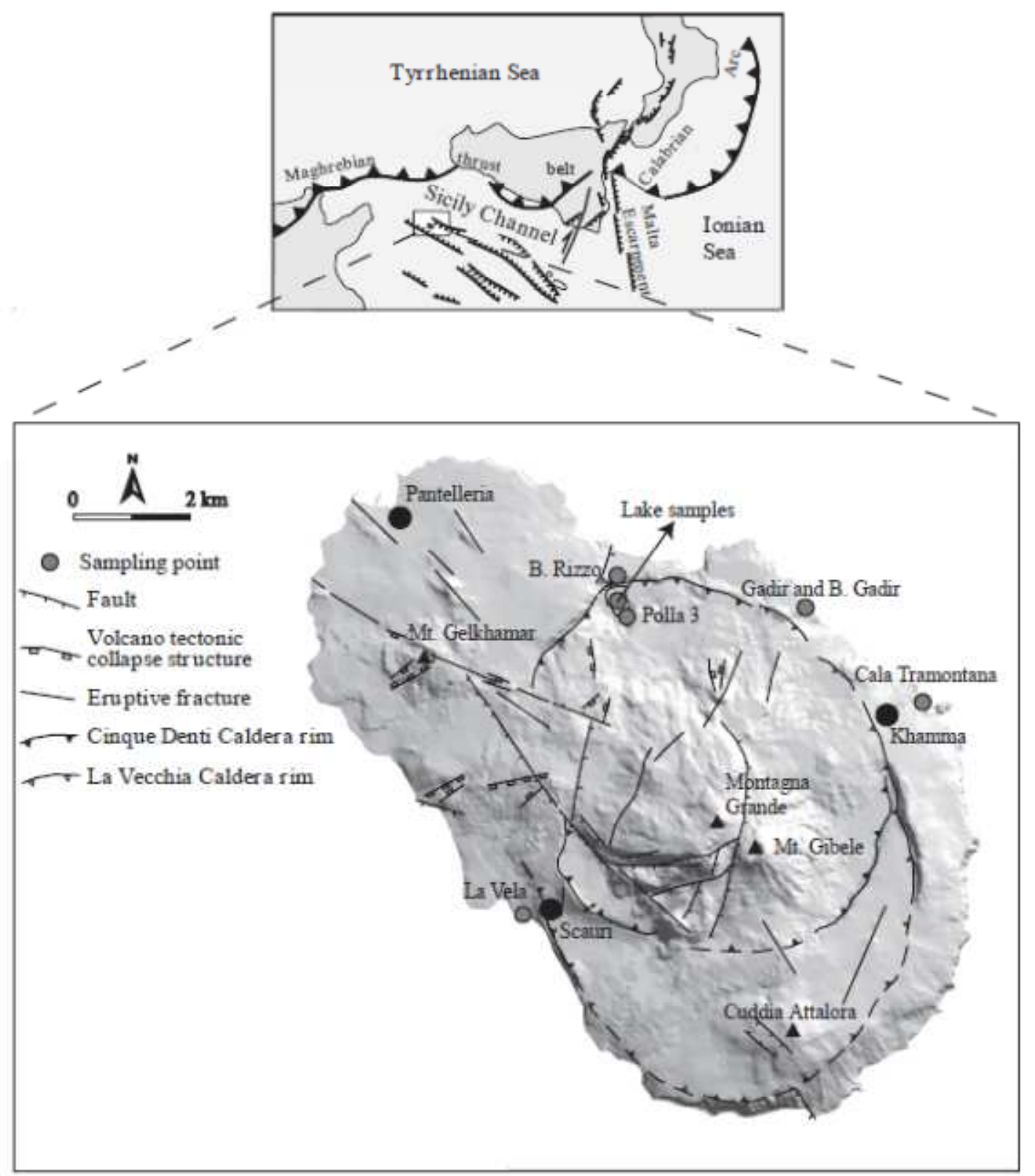

Figure 1 
a)

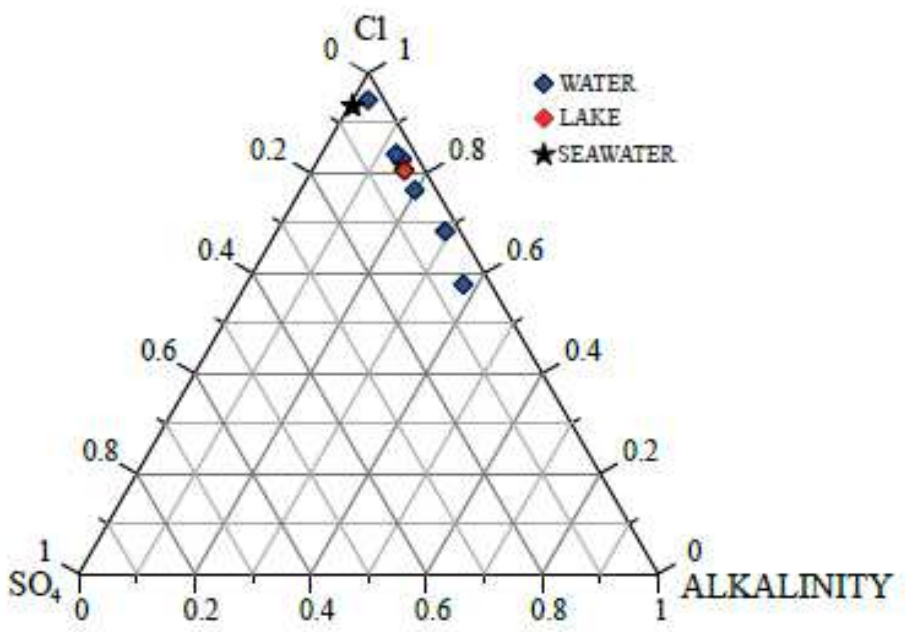

b)

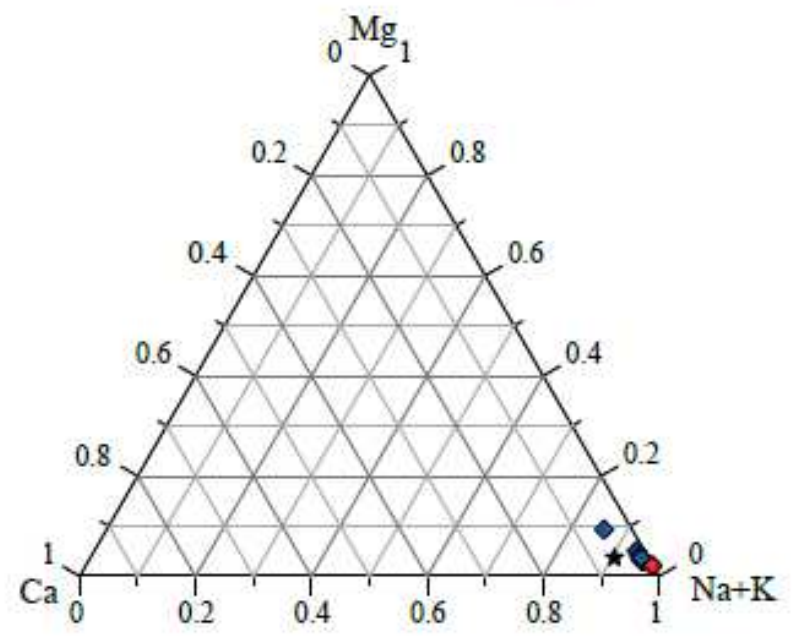

Figure 2 


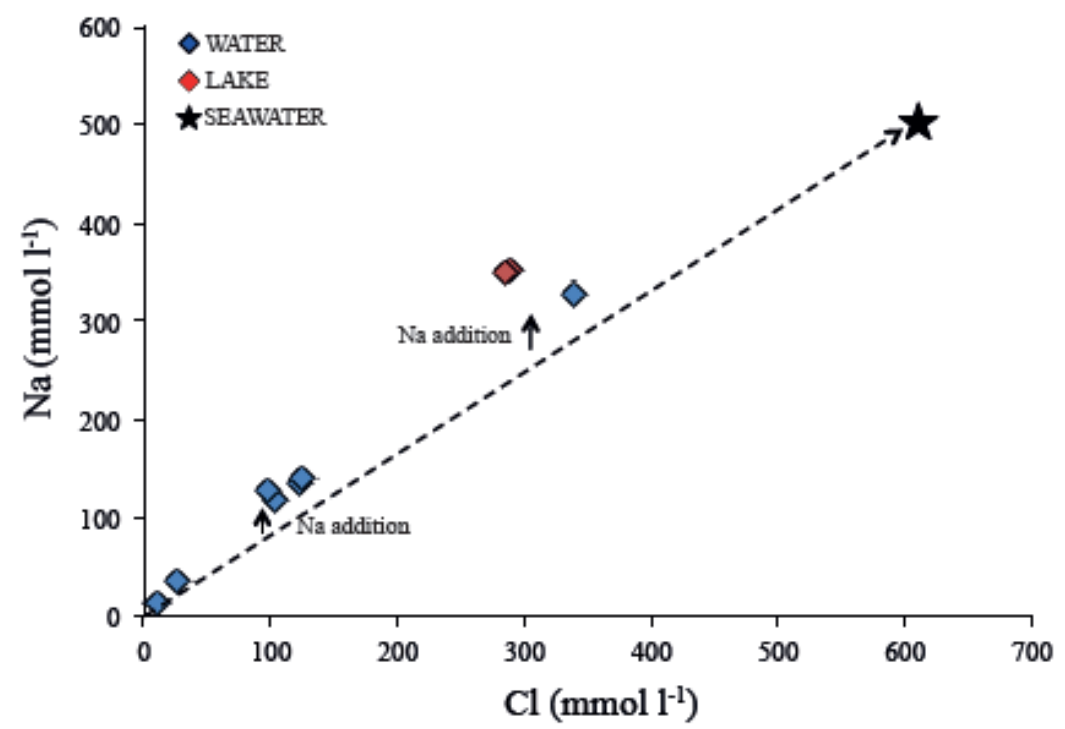

Figure 3 


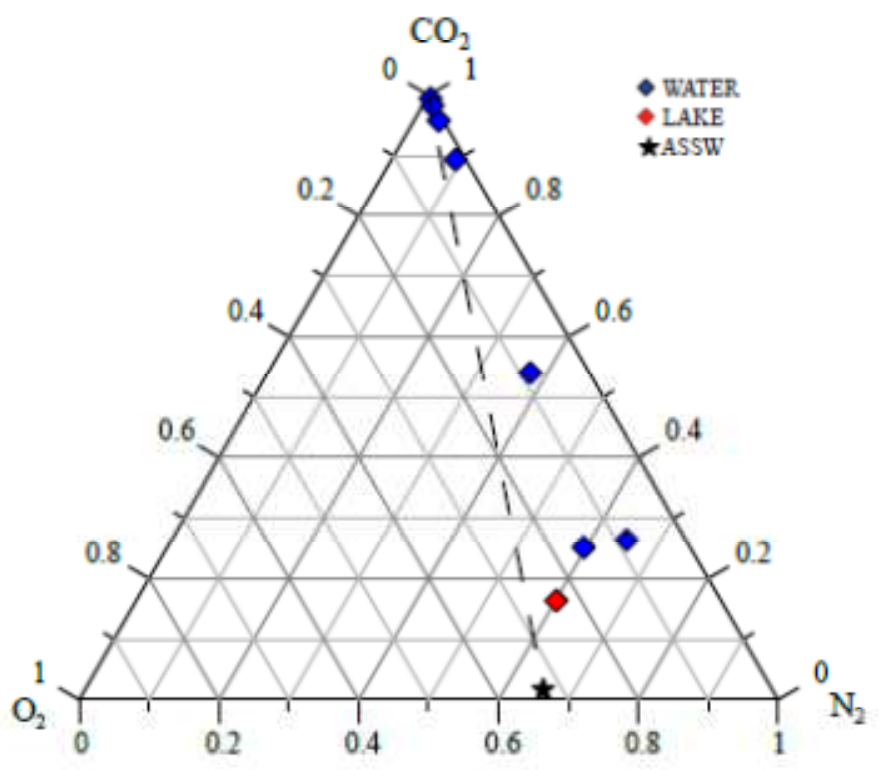

Figure 4

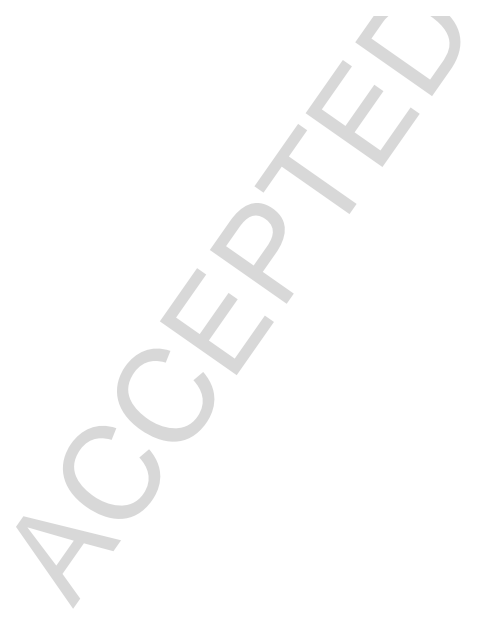



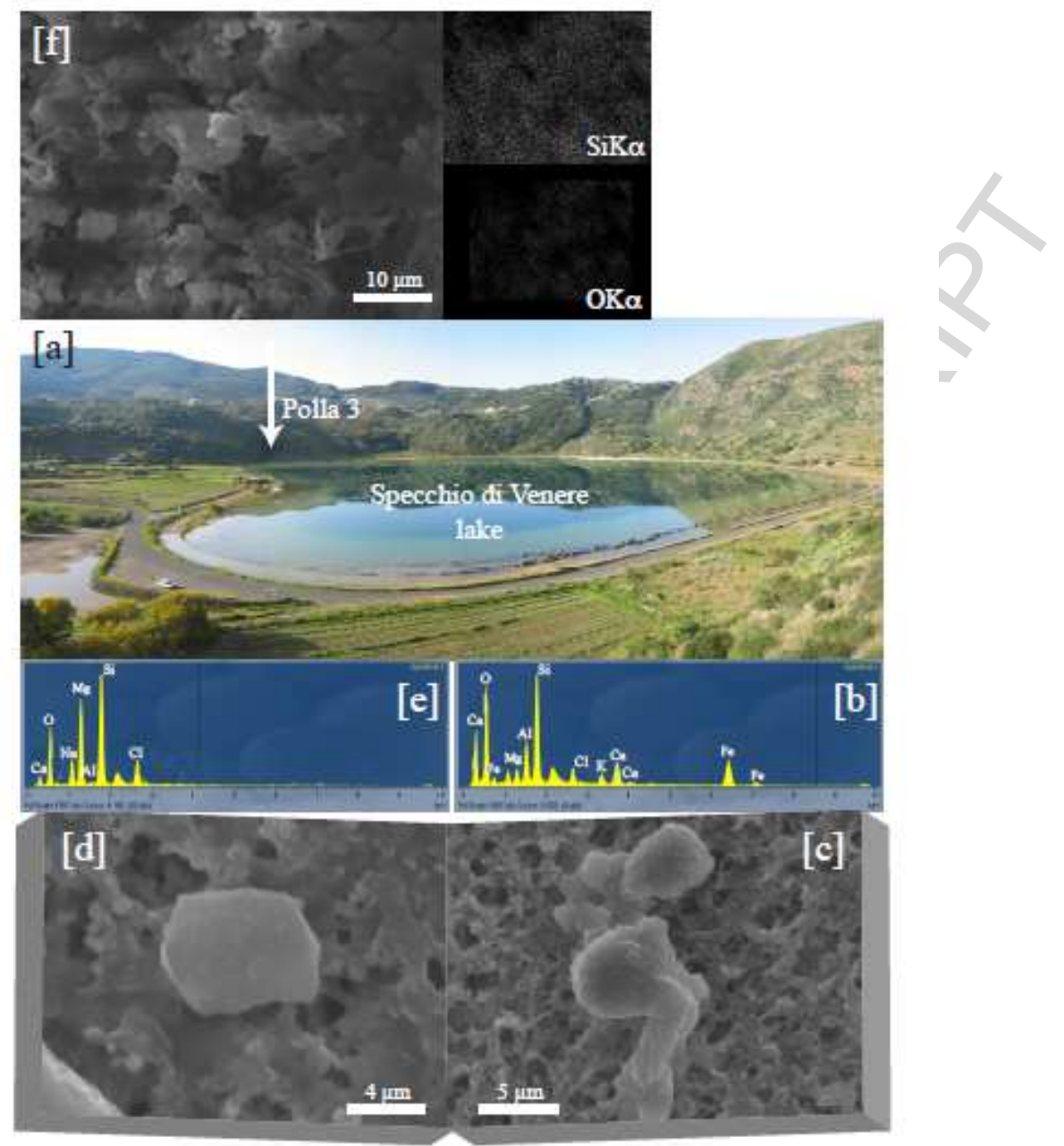

Figure 5

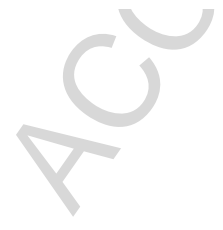




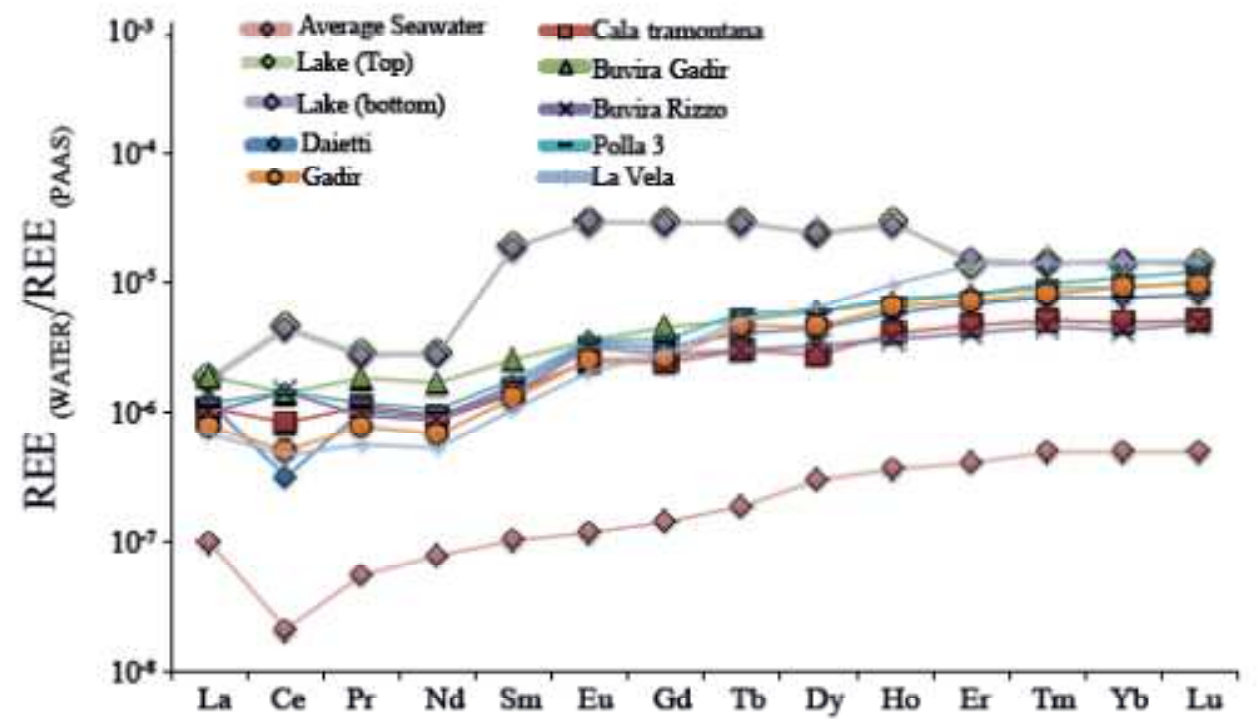

Figure 6 

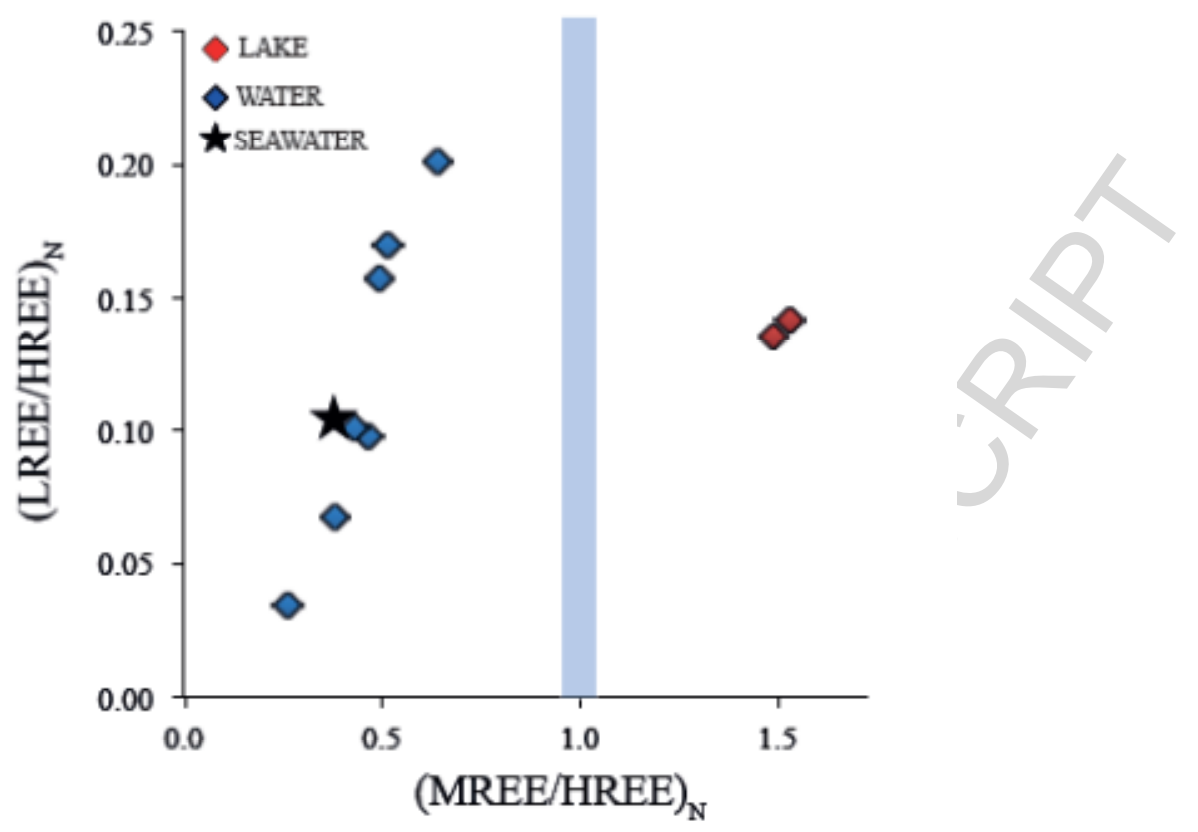

Figure 7

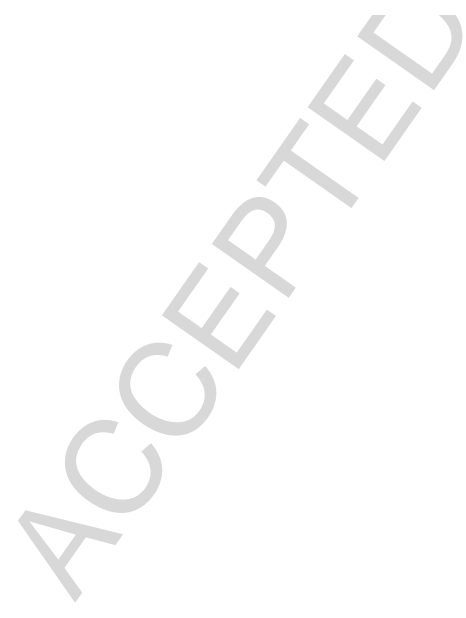



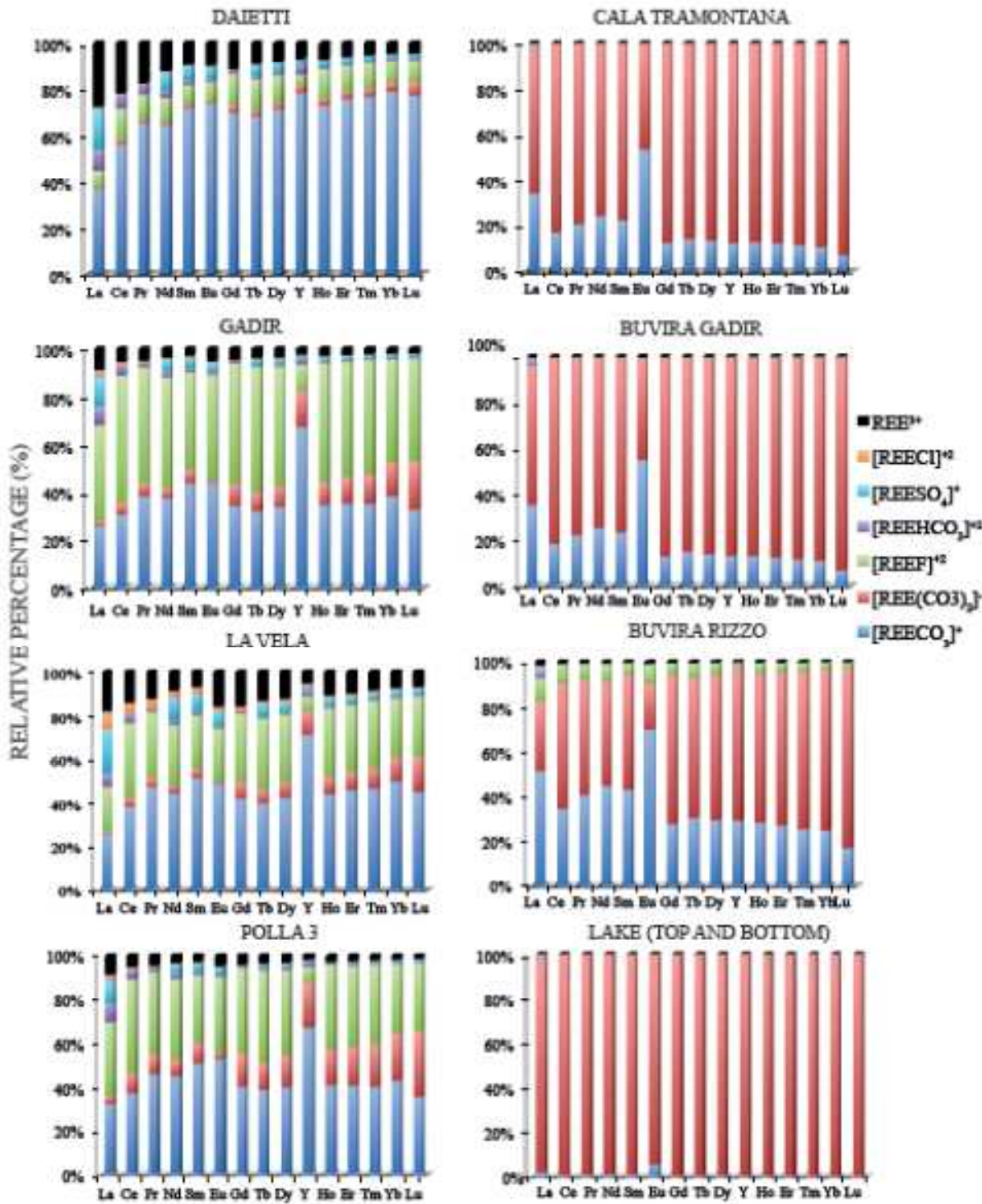

Figure 8 


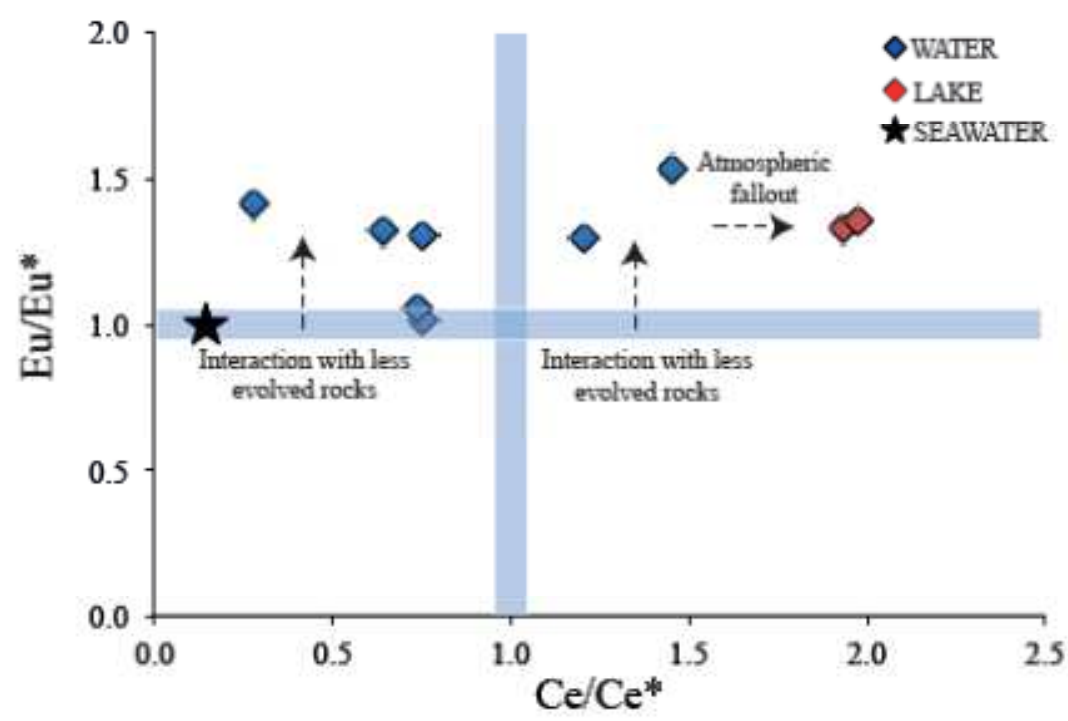

Figure 9

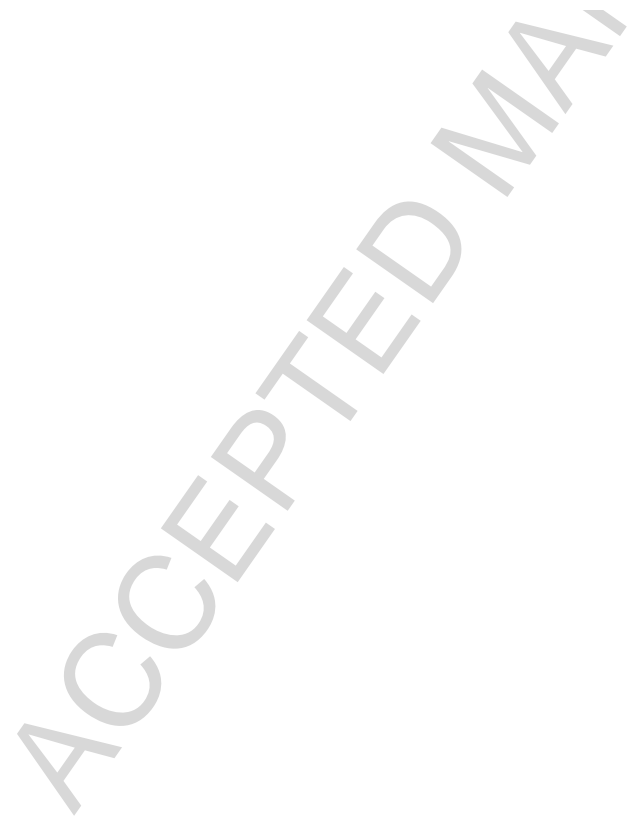




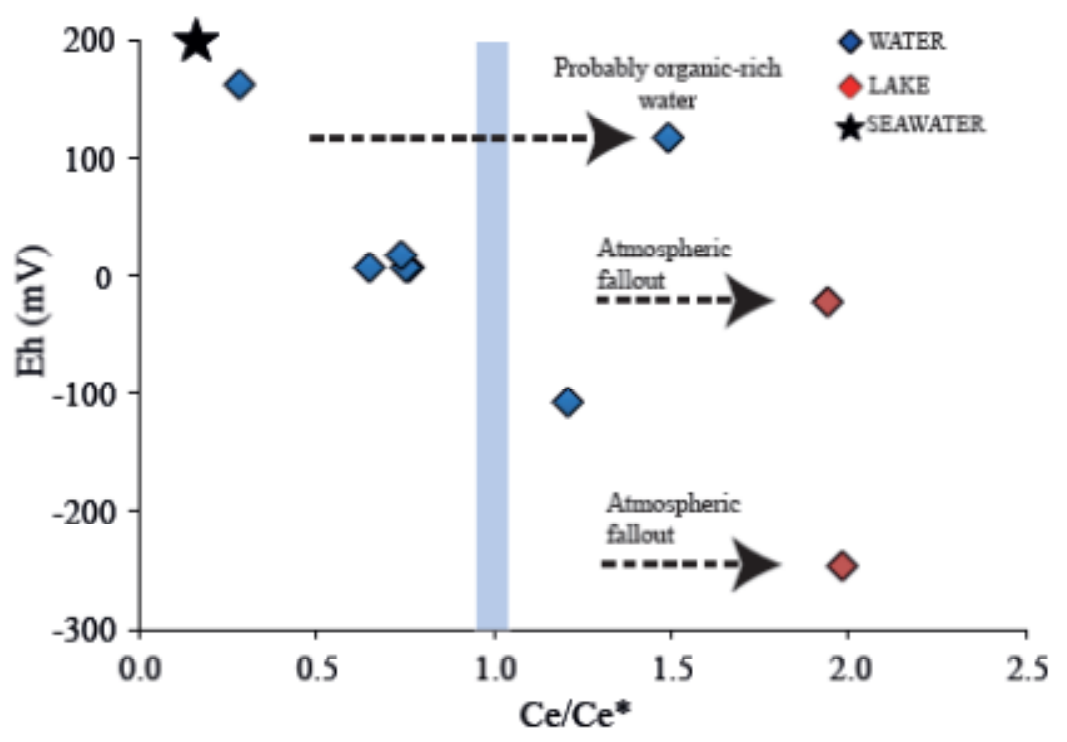

Figure 10

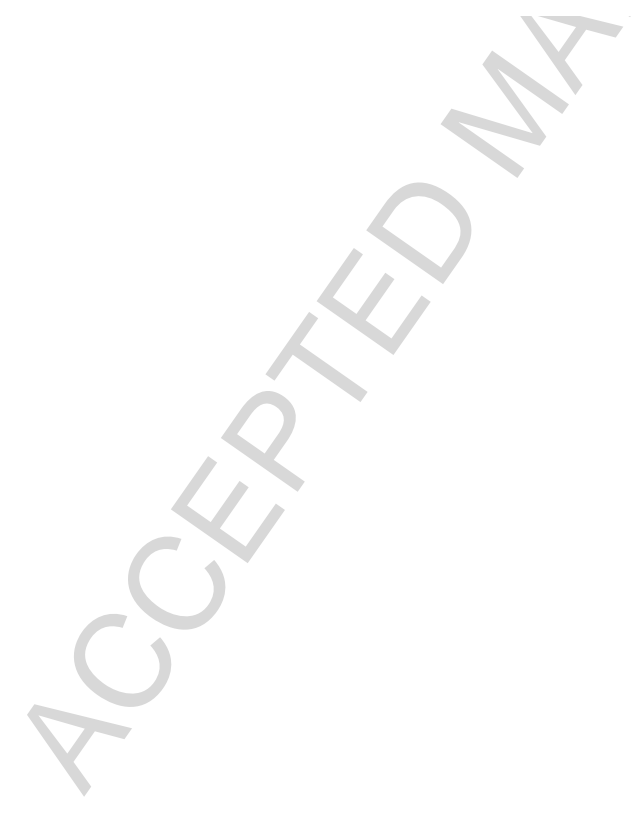




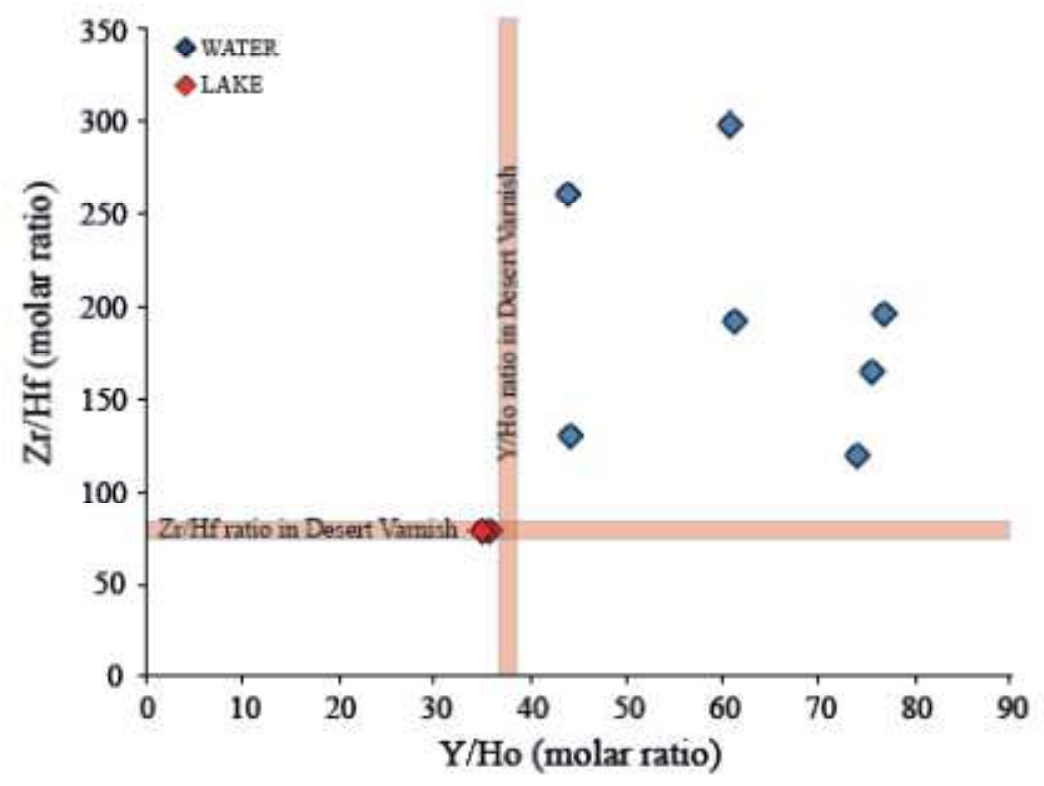

Figure 11

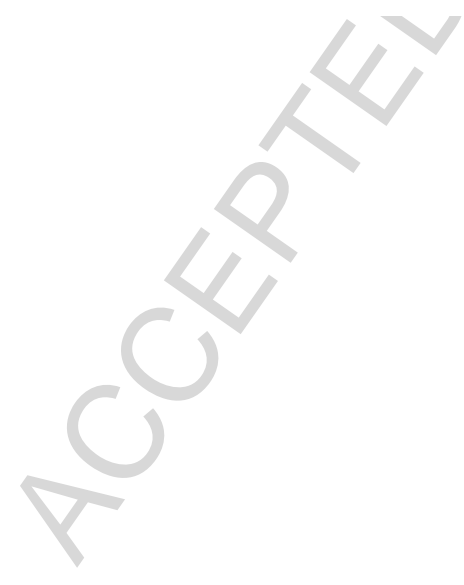




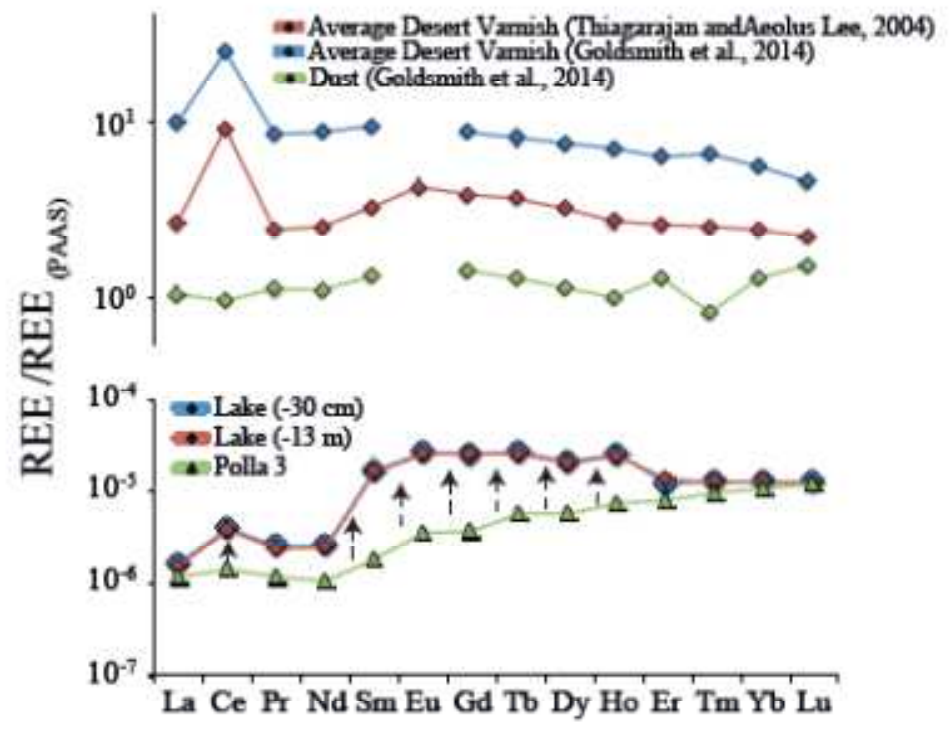

Figure 12 
Tab. 1 Chemical composition of cold and thermal waters. The chemical composition of major ions and $\mathrm{Si}$ is expressed in mmol $\mathrm{L}^{-1}, \mathrm{Fe}$ concentrations are expressed in $\mu \mathrm{mol} \mathrm{l}^{-1}$ while dissolved gases are expressed in $\mathrm{cc} \mathrm{L}^{-1}$ (STP).

\begin{tabular}{|c|c|c|c|c|c|c|c|c|c|c|c|c|c|c|c|c|c|c|c|}
\hline SA & $\begin{array}{c}\text { DAT } \\
\text { E }\end{array}$ & $\begin{array}{l}\mathbf{T} \\
\left({ }^{\circ}\right. \\
\mathbf{C})\end{array}$ & $\mathbf{p}$ & $\begin{array}{l}\text { Cond } \\
\cdot \\
(\dot{\mathrm{mS}} / \\
\mathrm{cm})\end{array}$ & $(\mathrm{m}$ & $\begin{array}{l}\mathbf{N} \\
\mathbf{a}\end{array}$ & $\mathbf{K}$ & $\begin{array}{c}\mathbf{M} \\
\mathbf{g}\end{array}$ & $\begin{array}{l}\mathbf{C} \\
\mathbf{a}\end{array}$ & $\mathbf{F}$ & Cl & $\mathbf{B r}$ & $\mathbf{S}$ & & $\mathbf{F e}$ & $\mathbf{S i}$ & $\mathrm{O}_{2}$ & $\mathbf{N}_{2}$ & $\begin{array}{l}\mathrm{C} \\
\mathrm{O}_{2}\end{array}$ \\
\hline \multirow{9}{*}{$\begin{array}{l}\text { Daietti } \\
\text { Cala } \\
\text { tramontan } \\
\text { a } \\
\text { Buvira } \\
\text { Gadir } \\
\text { Buvira } \\
\text { Rizzo }\end{array}$} & & 6 & & & & & 0. & 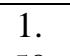 & 0. & 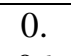 & 3. &. & & & & 1. & & 0 & \\
\hline & & .8 & & 2 & & & 00 & 50 & I & 06 & 40 & 01 & 7 & & 28 & 60 & 72 & 1 & 8 \\
\hline & & & & & & & & & & & & & & & 0. & & & & \\
\hline & /05 & 29 & 8. & & & 34 & 1. & 1. & 0. & . & 21 & 0. & 1. & & 02 & 1. & 3. & 12 & 5. \\
\hline & /14 & .4 & 45 & 4.3 & 8 & .0 & 02 & 10 & 44 & 42 & .2 & 06 & 32 & 7.00 & & 43 & 23 & 6 & 33 \\
\hline & /05 & 34 & 7. & & & 11 & 3. & 4. & 1. & 0 & 10 & 0. & 4. & & 0. & 3. & 2 & 11 & 16 \\
\hline & & .4 & 84 & 12.7 & 6 & 8 & 81 & 25 & 78 & 52 & 4 & 19 & 02 & 18.2 & 02 & 09 & 57 & 4 & . \\
\hline & 05 & 33 & 6. & & & 12 & 3. & 7. & 1. & 2. & 97 & 0. & 3. & & 1. & 2. & 1. & 7. & 3. \\
\hline & & .9 & 98 & 14.0 & 96 & 7 & 82 & 05 & 85 & 01 & .0 & 10 & 72 & 41.2 & $\begin{array}{c}08 \\
0 .\end{array}$ & 74 & 00 & 66 & 11 \\
\hline & & 54 & 6. & & 10 & 13 & 4. & 4. & 2. & 0 & 12 & 0 . & 4. & & 91 & 3. & 0 . & 1. & 35 \\
\hline . & & .6 & 44 & 15.8 & 8 & 6 & 17 & 31 & 12 & 57 & 3 & 22 & 21 & 21.4 & & 38 & 08 & 92 & 1 \\
\hline & & 53 & 6. & & & 13 & 4. & 6. & 2. & 0 & 12 & 0. & 4. & & 0 . & 3. & 0. & 4. & 31 \\
\hline 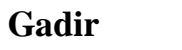 & & .8 & 32 & 16.4 & 7 & 9 & 34 & 21 & 06 & 67 & 5 & 18 & 99 & 19.2 & 85 & 28 & 9 & 6 & 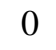 \\
\hline & /05 & 48 & 6. & & & 2 & 10 & 12 & 1 & 0. & 34 & 0. & 10 & & 0. & 2. & & 12 & 11 \\
\hline & & .3 & JU & 34.3 & 17 & 6 & .5 & .9 & 32 & 23 & 0 & 46 & .0 & 9.50 & 63 & 39 & 92 & .3 & 9 \\
\hline & $03 / 07$ & 27 & - & & & 35 & 11 & 8. & & . & 28 & 0 & 12 & & & & 4. & 11 & . \\
\hline cm) & & .2 & 97 & 3 & & & .6 & 00 & 65 & 64 & 9 & 43 & .6 & 56 & & - & 49 & 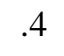 & 11 \\
\hline & & 26 & & & & . & 11 & & & & 28 & & & & & & & & \\
\hline & 11 & .8 & & 0.2 & & 0 & .5 & 02 & & ד & $J$ & J & & 0.0 & & & & & \\
\hline
\end{tabular}


Tab. 2 Saturation indexes of cold and thermal waters.

\begin{tabular}{|l|cccccc|}
\hline Sample & $\mathbf{S i O}_{\mathbf{2}}$ (amorphous) & Aragonite & Calcite & Dolomite & Hematite & Goethite \\
\hline Daietti & -0.07 & -1.6 & -1.4 & -1.4 & 1.0 & 0.01 \\
Cala tramontana & -0.17 & 0.33 & 0.48 & 2.6 & 6.4 & 2.7 \\
Buvira Gadir & 0.11 & 0.81 & 0.95 & 3.5 & 4.2 & 1.6 \\
Buvira Rizzo & 0.08 & 0.34 & 0.49 & 2.8 & 5.3 & 2.1 \\
Polla 3 & -0.02 & -0.18 & -0.03 & 1.5 & -2.7 & -1.9 \\
Gadir & -0.03 & -0.63 & -0.19 & 1.4 & 0.38 & -0.4 \\
La Vela & -0.11 & -0.36 & -0.21 & 1.4 & 1.4 & 0.2 \\
\hline
\end{tabular}


Tab. 3 REE, $\mathrm{Zr}$ and $\mathrm{Hf}$ dissolved in waters expressed in pmol $\mathrm{L}^{-1}$.

\begin{tabular}{|c|c|c|c|c|c|c|c|c|c|c|c|c|c|c|c|c|c|}
\hline SA & Y & $\mathbf{a}$ & e & Pr & va & m & Eu & Gd & b & $y$ & 10 & $\mathbf{E r}$ & Tm & $8 \mathrm{~b}$ & Lu & $\mathrm{Zr}$ & If \\
\hline & 56 & 3 & & 63. & 21 & 8. & 4. & 94. & 9. & & 4. & & 18. & & 19. & & .3 \\
\hline Dais & 7 & 5 & 180 & 5 & 9 & 7 & 0 & 8 & 5 & 125 & 9 & 117 & 0 & 22 & & 206 & 1 \\
\hline al & 180 & 29 & & 69. & 22 & 53. & 17. & 70 & 14. & 79. & 24. & 9. & 12. & 8. & 2. & & 33. \\
\hline \multirow[t]{2}{*}{ tramontana } & 7 & 9 & 474 & 4 & 3 & ? & 7 & 8 & 6 & 5 & 0 & 2 & 0 & 9 & 4 & 3989 & 6 \\
\hline & 260 & 52 & & & 39 & 93. & 25. & & 24. & & 42. & & 21. & & 24. & & 4.3 \\
\hline \multirow[t]{2}{*}{ Buvira Gadir } & 9 & 2 & 799 & 115 & 2 & 1 & 1 & 132 & 4 & 170 & 1 & 137 & 6 & 149 & 8 & 833 & 4 \\
\hline & & 27 & & 59. & 20 & 51. & 22. & 81. & 14. & 94. & 21. & 69. & 10. & 69. & 11. & & 9.2 \\
\hline \multirow[t]{2}{*}{ Buvira Rizzo } & 56 & 8 & 817 & 9 & 2 & 1 & 5 & 9 & 6 & 3 & 6 & 1 & 8 & 9 & 9 & 1206 & 4 \\
\hline & 200 & 32 & & 73. & 24 & 66. & 24. & & 27 & & 44. & & 23. & & 29. & & 8.4 \\
\hline \multirow[t]{2}{*}{ Polla 3} & 0 & 5 & 810 & 7 & 5 & 2 & 9 & 108 & 9 & 168 & 9 & 137 & 3 & 177 & 7 & 2193 & 0 \\
\hline & 237 & 21 & & 48. & 16 & 46. & 18. & 76. & 22 & & 38. & & 19. & & 24. & & 8.4 \\
\hline \multirow[t]{2}{*}{ Gadi } & 6 & 5 & 287 & 7 & 1 & 9 & 0 & 8 & & & 7 & 123 & 2 & 149 & 3 & 2510 & 0 \\
\hline & 455 & 19 & & 35. & 12 & 38. & 14. & 83. & & & 58. & & 33. & & 36. & & 3.1 \\
\hline \multirow[t]{2}{*}{ La Vela } & 7 & 0 & 265 & 6 & 5 & 5 & 4 & 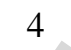 & & & 5 & 229 & 6 & 231 & 4 & 620 & 7 \\
\hline & 564 & 45 & 228 & & 59 & & & & & & & & 30. & & 31. & 2313 & \\
\hline \multirow[t]{2}{*}{ Lake $(-30 \mathrm{~cm})$} & 0 & 5 & 9 & 157 & 5 & 617 & 186 & 760 & 26 & 614 & 155 & 205 & 7 & 204 & 0 & 0 & 30 \\
\hline & 522 & 42 & 219 & & 58 & & & & & & & & 30. & & 30. & 2215 & \\
\hline ake (. & 8 & 1 & 7 & 149 & 5 & 604 & 183 & 740 & 123 & 595 & 148 & 233 & 0 & 213 & 1 & 0 & 29 \\
\hline
\end{tabular}

